\title{
Controls on the distribution of cosmogenic ${ }^{10} \mathrm{Be}$ across shore platforms
}

\author{
Martin D. Hurst ${ }^{1,2}$, Dylan H. Rood $^{3}$, and Michael A. Ellis ${ }^{2}$ \\ ${ }^{1}$ School of Geographical and Earth Sciences, University of Glasgow, Glasgow, G12 8QQ, UK \\ ${ }^{2}$ British Geological Survey, Nicker Hill, Keyworth, Nottingham, NG12 5GG, UK \\ ${ }^{3}$ Department of Earth Science and Engineering, Imperial College London, South Kensington Campus, \\ London, SW7 2AZ, UK \\ Correspondence to: Martin D. Hurst (martin.hurst@glasgow.ac.uk)
}

Received: 28 July 2016 - Published in Earth Surf. Dynam. Discuss.: 4 August 2016

Revised: 11 October 2016 - Accepted: 24 November 2016 - Published: 26 January 2017

\begin{abstract}
Quantifying rates of erosion on cliffed coasts across a range of timescales is vital for understanding the drivers and processes of coastal change and for assessing risks posed by future cliff retreat. Historical records cover at best the last 150 years; cosmogenic isotopes, such as ${ }^{10} \mathrm{Be}$ could allow us to look further into the past to assess coastal change on millennial timescales. Cosmogenic isotopes accumulate in situ near the Earth surface and have been used extensively to quantify erosion rates, burial dates and surface exposure ages in terrestrial landscapes over the last 3 decades. More recently, applications in rocky coast settings have quantified the timing of mass wasting events, determined long-term averaged rates of cliff retreat and revealed the exposure history of shore platforms. In this contribution, we develop and explore a numerical model for the accumulation of ${ }^{10} \mathrm{Be}$ on eroding shore platforms. In a series of numerical experiments, we investigated the influence of topographic and water shielding, dynamic platform erosion processes, the presence and variation in beach cover, and heterogeneous distribution of erosion on the distribution of ${ }^{10} \mathrm{Be}$ across shore platforms. Results demonstrate that, taking into account relative sea level change and tides, the concentration of ${ }^{10} \mathrm{Be}$ is sensitive to rates of cliff retreat. Factors such as topographic shielding and beach cover act to reduce ${ }^{10} \mathrm{Be}$ concentrations on the platform and may result in overestimation of cliff retreat rates if not accounted for. The shape of the distribution of ${ }^{10} \mathrm{Be}$ across a shore platform can potentially reveal whether cliff retreat rates are declining or accelerating through time. Measurement of ${ }^{10} \mathrm{Be}$ in shore platforms has great potential to allow us to quantify long-term rates of cliff retreat and platform erosion.
\end{abstract}

1

\section{Introduction}

There is societal need to assess the rates, and the change of rates, at which cliffed coastlines will erode in the face of changing sea levels and wave climates that may result in more energetic coasts (Bray and Hooke, 1997; Trenhaile, 2010; Ashton et al., 2011; Barkwith et al., 2014). The lack of long-term records of cliff and shore-platform erosion rates is a key problem to address (Trenhaile, 2014). An emerging tool to assess past rates of cliff retreat comes from the accumulation of cosmogenic isotopes such as ${ }^{10} \mathrm{Be}$ across active marine platforms that are generated via cliff retreat (Re- gard et al., 2012; Choi et al., 2012). These isotopes have the potential to yield rates of cliff recession and shore-platform erosion over millennial timescales (Hurst et al., 2016). These records will provide a long-term context for historical and present rates of cliff recession and facilitate the calibration of dynamic models of shore platform erosion and cliff recession (Trenhaile, 2000; Walkden and Hall, 2005; Ashton et al., 2011; Matsumoto et al., 2016). The erosion of rocky coastlines is the result of a dynamic suite of processes that operate at the coast (Sunamura, 1992; Kennedy et al., 2014). The production of cosmogenic isotopes in the shore platform is in turn influenced by these processes and the resultant mor- 
phological evolution of the coast (Regard et al., 2012). This paper explores the factors that influence the spatial patterns of ${ }^{10} \mathrm{Be}$ across emergent platforms, with the objective of allowing us to better constrain quantitative measures of cliff retreat rate.

Estimates of sea cliff retreat rates over decadal to centennial timescales have been made by observing the change in position of the cliff top, derived from historical maps, aerial photography, satellite imagery and field surveys (e.g. Bray and Hooke, 1997; Costa et al., 2004; Dornbusch et al., 2006; Brooks and Spencer, 2010; Katz and Mushkin, 2013). Observations are limited by the length of historical records, which span at best the late 1800s to present. Sunamura (2015) demonstrated that longer-term records are needed. The return period of coastal mass wasting events, the principal mechanisms of coastal cliff retreat, may in some cases be much longer than these historical records (Recorbet et al., 2010). Methods to estimate long-term rates of cliff retreat are required in order to time average rates across multiple failure events. It is important that modern observations of sea cliff retreat can be placed in the context of long-term coastal evolution, over time spans unaffected by human intervention at the coast. Long-term records of cliff retreat in response to relative sea level (RSL) change are required in order to predict how coastal erosion may proceed into the future in the face of anticipated RSL rise and increased storminess. Yet, by their very nature, eroding coastlines leave scant evidence of any former state, and their form reflects little about their longterm erosional trajectories (Matsumoto et al., 2016). Cosmogenic isotopes have the potential to reveal the long-term history of coastal change and to quantify process rates along rocky coastlines (Recorbet et al., 2010; Choi et al., 2012; Regard et al., 2012; Rogers et al., 2012; Hurst et al., 2016).

Cosmogenic isotopes are produced by the interaction of cosmic rays with target elements in the upper few metres of the Earth surface. Measurements of their abundance (particularly ${ }^{10} \mathrm{Be}$ ) in rock and soil samples (in situ) provides a versatile geochronometer to quantify how long a sample has been exposed at/near the Earth surface or interpret how rapidly it has been eroded (Balco et al., 2008; Dunai, 1995; Granger et al., 2013). Recently, these techniques have been used for application in rocky coast settings. Recorbet et al. (2010) used ${ }^{10} \mathrm{Be}$ to demonstrate that a calcareous sandstone sea cliff in south-eastern France last failed around $3.5 \mathrm{ka}$ (thousand years before present), suggesting a long return period for sea cliff retreat events at that site. Rogers et al. (2012) assessed long-term shoreline recession in Washington, USA, by using ${ }^{10} \mathrm{Be}$ to date large boulders, released and abandoned on the shore platform during recession of till bluffs.

The measurement of ${ }^{10} \mathrm{Be}$ concentrations from shore platform samples to estimate long-term rates of sea cliff retreat was pioneered by Regard et al. (2012) working on the flint-bearing chalk coastline near Mesnil-Val, France. Regard et al. (2012) developed a numerical model to predict the concentration of ${ }^{10} \mathrm{Be}$ on shore platforms as a function of the rate of cliff retreat. They minimized residuals between model results and a transect of eight ${ }^{10} \mathrm{Be}$ concentration measurements from across the shore platform in order to estimate long-term average sea cliff retreat rates that were similar to estimates from historical observations; however, the uncertainties on the analyses were large and limited the resolution and confidence of the comparison. Building on the approach of Regard et al. (2012), Hurst et al. (2016) quantified long-term rates of cliff retreat from ${ }^{10} \mathrm{Be}$ concentrations measured in two sample transects on the flint-bearing chalk shore platforms in East Sussex, UK. Rates during much of the Holocene were significantly slower than changes observed in the last 150 years, leading Hurst et al. (2016) to suggest that cliff retreat rates accelerated some time between 600 and 150 years ago.

Some shore platforms may have formed during the Holocene and thus be entirely contemporaneous features, whilst others, particularly wide platforms in resistant lithologies, have been interpreted as inherited features, formed during previous sea level high stands and reoccupied during the Holocene (e.g. Chao et al., 2003). Evidence of the antiquity of shore platforms may be revealed by cosmogenic isotopes. For example, Choi et al. (2012) measured ${ }^{10} \mathrm{Be}$ concentrations in shore platforms cut into resistant lithologies on the Korean coast. High concentrations were consistent with modelled ages extending back as far as $142 \mathrm{ka}$, and importantly, these ages did not correct for weathering and erosion and thus should be considered as minimum ages. Thus, Choi et al. (2012) conclude that these platforms are at least partially inherited features, originating in the Pleistocene.

On a contemporary shore platform (formed during the Holocene), the theoretical distribution of ${ }^{10} \mathrm{Be}$ concentrations on an eroding shore platform generally increases and then decreases with distance from the modern cliff (Fig. 1). In the near-shore zone, ${ }^{10} \mathrm{Be}$ concentrations increase offshore because the shore platform has been exposed for longer. However, the rate of ${ }^{10} \mathrm{Be}$ production decreases offshore because cover by seawater attenuates the cosmic ray flux; hence, the amount of cosmic radiation received by the platform decreases with increased water depth. Additionally, downwear of the coastal platform surface removes the highest-concentration ${ }^{10} \mathrm{Be}$ rock from the surface and exhumes lower concentrations that were previously below the surface (Fig. 1). The combined result of these factors is a "humped" distribution of ${ }^{10} \mathrm{Be}$ concentrations. The magnitude of the maximum concentration is predicted to be proportional to the long-term averaged rate of sea cliff retreat (Regard et al., 2012); higher rates of sea cliff retreat result in lower ${ }^{10} \mathrm{Be}$ concentrations in the platform (Fig. 1). Tides modify these predictions by altering the distribution of ${ }^{10} \mathrm{Be}$ production across the shore platform due to the attenuation of cosmic rays in the water column. Regard et al. (2012) showed that increasing tidal range causes the cross-shore position of the peak concentration to migrate seaward. Regard et al. (2012) also demonstrated that, whilst rising RSL in- 


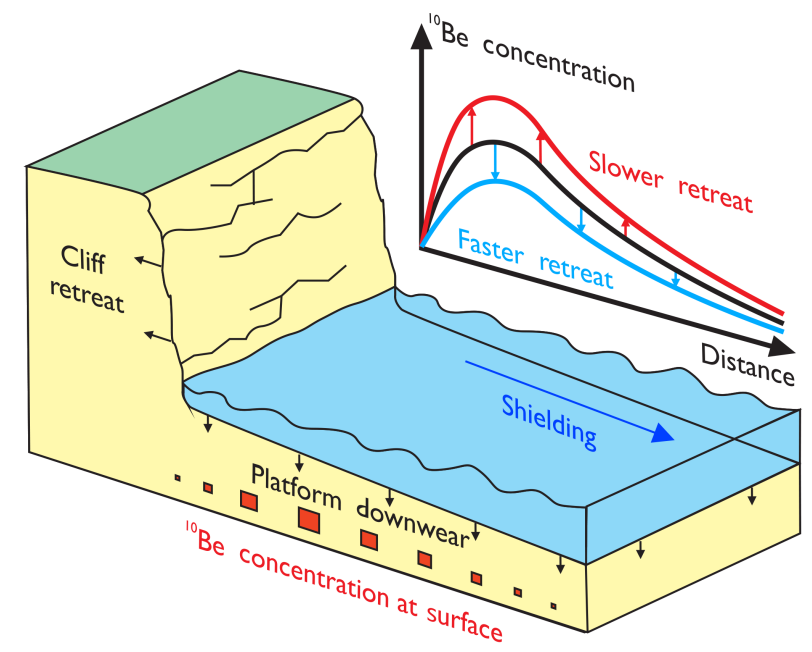

Figure 1. Schematic diagram of a rocky coast showing the expected distribution of ${ }^{10} \mathrm{Be}$ across a shore platform. Cliff retreat exposes pristine platform with low ${ }^{10} \mathrm{Be}$ concentrations. Exposure time increases with distance from the cliff (increasing ${ }^{10} \mathrm{Be}$ concentrations), but platform downwear removes ${ }^{10} \mathrm{Be}$-rich rock, and increased water shielding reduces ${ }^{10} \mathrm{Be}$ production offshore. The result is a hump-shaped distribution where the magnitude of the hump is inversely proportional to the rate of cliff retreat.

creases water depth, counter-intuitively it can result in higher ${ }^{10} \mathrm{Be}$ concentrations on the shore platform due to an associated reduction in platform downwear rates.

Several other factors may influence the accumulation of ${ }^{10} \mathrm{Be}$ in shore platforms that have not been accounted for in previous coastal studies. Shore platforms may erode through gradual (e.g. weathering and abrasion) or episodic (e.g. quarrying) processes (Dornbusch and Robinson, 2011; Naylor et al., 2016), and the relative influence of these processes on the distribution of ${ }^{10} \mathrm{Be}$ has yet to be explored. Similarly, the assumption that shore platforms evolve in morphological steady state (i.e. landward translation of a constant shore profile morphology through time that tracks relative sea level change), which is sometimes also referred to as equilibrium retreat, may not always be appropriate (Dickson et al., 2013). The style of coastal evolution is expected to influence the distribution of ${ }^{10} \mathrm{Be}$ across a shore platform. Modelling studies suggest that shore platform gradients may decline through time and platforms widen (Trenhaile, 2000; Walkden and Hall, 2005). Talus cones and beaches are often found fringing coastal cliffs, covering shore platforms and therefore shielding them from cosmic rays. ${ }^{10} \mathrm{Be}$ concentrations in the shore platform would be reduced (Regard et al., 2012). Coastal cliffs may shield the platform from a portion of the incoming cosmic ray flux, thus also reducing ${ }^{10} \mathrm{Be}$ production in the near-shore zone, and shielding is proportional to cliff height.
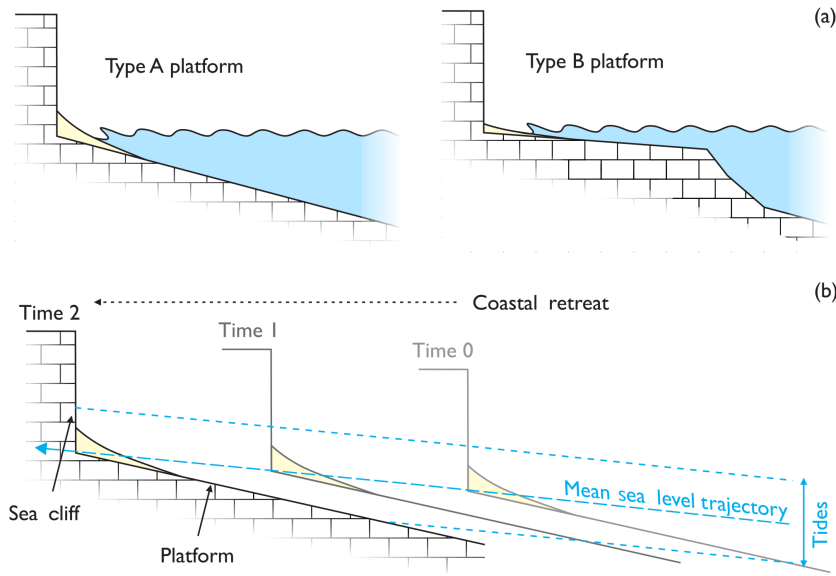

(b)

Figure 2. (a) Endmember types of shore platform as defined by Sunamura (1992). (b) Illustration of steady-state shore profile retreat subject to relative sea level rise.

In this study we quantified the sensitivity of platform ${ }^{10} \mathrm{Be}$ concentrations to topographic shielding, various processes of platform erosion/downwear, the presence/absence of beach cover and transience in shore profile evolution. Our intention is to explore the general case parsimoniously to better understand controls on ${ }^{10} \mathrm{Be}$ concentrations, rather than to make accurate predictions for any specific field site. In doing so, we only considered the development of shore platforms during the Holocene, over the timescale during which eustatic sea level has been relatively stable ( $7 \mathrm{ka}$ to present). We addressed this with a numerical model coupling crossshore coastal evolution and ${ }^{10} \mathrm{Be}$ production to explore the potential for quantifying coastal retreat rates from ${ }^{10} \mathrm{Be}$ concentration measurements.

\section{Numerical model for shore platform evolution and ${ }^{10} \mathrm{Be}$ production}

Cliffed, rocky coasts are commonly fronted by shore platforms that have previously been classified into two types (Sunamura, 1992). Type-A platforms are characterized by a gently sloping erosional platform surface extending offshore beyond maximum low water. Type-B platforms are shallow-gradient to sub-horizontal and terminate at their seaward edge at maximum low water through a scarp (Fig. 2a). Numerical models of shore platform evolution have successfully recreated both of these endmember morphologies but have revealed that there are a range of other possible morphologies in between, for example sloping platforms terminating in a scarp (e.g. Trenhaile, 2000; Walkden and Hall, 2005; Matsumoto et al., 2016).

Numerical models of platform evolution demonstrate that shore platforms and adjacent sea cliffs tend towards a morphological steady state, Under such conditions the morphology may reflect the combination of RSL change, tides and 
wave energy availability. However, the assumption of steadystate retreat may not always be applicable (Dickson et al., 2013). We expected the style of platform evolution to be important for the distribution of ${ }^{10} \mathrm{Be}$ across a shore platform. Moreover, micro-erosion meter measurements of platform downwear suggest that downwear is not uniform across the shore profile but tends to be faster in the upper intertidal zone and decline with depth (Porter et al., 2010), and to explore the influence of such a distribution on ${ }^{10} \mathrm{Be}$ concentrations, a dynamic morphological model was required.

Therefore, two different morphological models are used in this study. The first assumes steady-state evolution of the shore profile, such that coastal morphology does not change its form through time, and a constant cliff-platform geometry is translated landward through time. The second model is a dynamic shore platform evolution model similar to that of Trenhaile (2000) that can reproduce a range of platform geometries. These two approaches are described in more detail in the subsequent sections.

\subsection{Steady-state coastal retreat}

We initially assumed that coastal cliff and shore platform evolution can be considered a steady-state process: a constant coastal cross-section profile is translated landward through time, with the elevation of the cliff-platform junction tracking RSL (Fig. 2b). As such, platform downwear was assumed proportional to the product of cliff retreat rate and platform gradient $\alpha$ (Regard et al., 2012).

A steady-state approach assumes platform downwear is gradual and constant across the entire profile and proportional to the rate of cliff retreat. We are therefore assuming that the combined mechanical and chemical processes that can cause shore platform lowering culminate in constant and gradual downwear in this case. Wave energy, tidal range and the types of processes operating on the shore platform do not factor in to the morphological development explicitly but rather are assumed to combine to cause steady-state retreat. Several coastal platforms have been observed to erode due to quarrying and block removal (e.g. Dornbusch and Robinson, 2011; Naylor et al., 2016). In order to explore the potential implication of these erosion processes for the accumulation of ${ }^{10} \mathrm{Be}$ in a shore platform, we also evolved a series of stepped platforms by steady-state retreat.

\subsection{Numerical model for dynamic platform evolution}

We developed a simple numerical model for shore profile evolution (the ROck and BOttom COastal Profile (RoBoCoP) Model), broadly similar to those of Sunamura (1992), Anderson et al. (1999) and Trenhaile (2000). These models assume that horizontal erosion at the water level is proportional to the availability of wave energy (or by proxy, wave height). The shore profile was considered as a regularly spaced vertical stack of cells with horizontal position $x$
$[L]$ (all dimensions denoted in square brackets as $[L]$ ength, $[M]$ ass and $[T]$ ime). The change in position of the coast at the water level $x_{\mathrm{w}}[L]$ through time $t[T]$ was assumed to be linearly proportional to the height of breaking waves reaching the shore $H_{\mathrm{c}}[L]$ :

$\frac{\mathrm{d} x_{\mathrm{w}}}{\mathrm{d} t}=K \rho_{\mathrm{w}} g H_{\mathrm{c}}$.

In Eq. (1), $K\left[L^{2} \cdot T \cdot M^{-1}\right]$ is a coefficient related to the resistance of bedrock to erosion, $\rho_{\mathrm{w}}\left[M \cdot L^{-3}\right]$ is the density of water and $g\left[L \cdot T^{-2}\right]$ is acceleration due to gravity. The water depth $h_{\mathrm{w}}[L]$ for the initiation of wave breaking $h_{\mathrm{b}}[L]$ was related to wave height $H[L]$, such that breaking wave height $H_{\mathrm{b}}[L]$ is the wave height that exceeds a water-depthdependent threshold:

$H_{\mathrm{b}}=0.78 h_{\mathrm{b}}$.

Breaking wave height was determined by iterating deepwater wave conditions from deep to shallow water and calculating $h_{\mathrm{w}}$ according to linear wave theory (e.g. Hurst et al., 2015) or following an empirical relationship relating breaking wave conditions to offshore wave conditions (e.g. Komar and Gaughan, 1972):

$H_{\mathrm{b}}=0.39 g^{\frac{1}{5}} T^{\frac{2}{5}} H_{0}^{\frac{4}{5}}$.

In Eq. (3), $T[T]$ is wave period and $H_{0}[L]$ is deep-water wave height. If Eq. (3) is used to predict $H_{\mathrm{b}}$, Eq. (2) can be inverted to determine the water depth at which wave breaking begins. Following wave breaking, wave height is assumed to decay exponentially with distance across the platform, such that the wave height at the water line can be described as

$H_{\mathrm{c}}=H_{\mathrm{b}} e^{-k W_{\mathrm{s}}}$.

In Eq. (4), $W_{\mathrm{s}}[L]$ is the width of the surf zone, measured from $x\left(h_{\mathrm{w}}=h_{\mathrm{b}}\right)$ to $x\left(h_{\mathrm{w}}=0\right)$ and $k$ is a dimensionless constant that represents the rate of breaking wave energy dissipation, which reflects bed roughness in the surf zone (Trenhaile, 2000); we used $k=0.02$ throughout. These properties are all time dependent because the elevation of the water surface varies due to tides (superimposed onto any RSL change). The distribution of erosion across the platform was integrated across the tidal cycle of period $T_{\mathrm{t}}[T]$. Platform erosion below the water line was assumed to decline exponentially with water depth $h_{\mathrm{w}}$. Combining Eqs. (1)-(4), the governing equation for evolution of the shore platform becomes:

$$
\frac{\mathrm{d} x}{\mathrm{~d} t}=K \rho_{\mathrm{w}} g \int_{t=0}^{T_{\mathrm{t}}} H_{\mathrm{b}}(t) e^{h_{\mathrm{w}}(t)-k W_{\mathrm{s}(t)}} \quad\left\{h_{\mathrm{w}} \in \mathbb{R}: h_{\mathrm{w}} \geq 0\right\} .
$$

\subsection{Beach cover}

In order to explore the influence of beach cover on the accumulation of ${ }^{10} \mathrm{Be}$ on the coastal platform, we approximated 


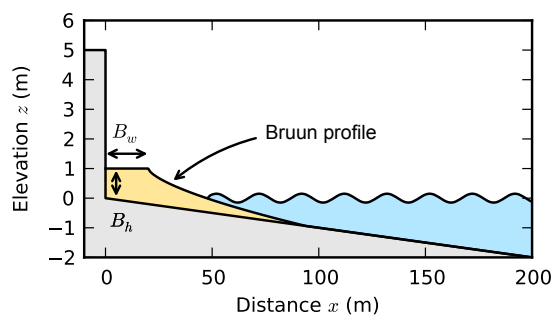

Figure 3. Example of beach model used in modelling ${ }^{10} \mathrm{Be}$ accumulation in a shore platform. Beach is defined by a beach width $B_{\mathrm{W}}$ and berm height $B_{\mathrm{h}}$ and a Bruun profile (Bruun, 1954) seaward of the defined beach width.

the profile morphology of beaches using a power-law function (Fig. 3; Bruun, 1954):

$z_{\mathrm{b}}=z_{\mathrm{b} 0}-A x_{\mathrm{b}}{ }^{m}$.

In Eq. (6), $z_{\mathrm{b}}[L]$ is the elevation of the beach, $z_{\mathrm{b} 0}[L]$ is the elevation of the beach at the top of the berm, $A\left[L^{1 / 3}\right]$ is a scaling parameter that relates to the size of beach material and $m$ is a dimensionless exponent that represents the distribution of wave energy dissipation on the shoreface. We used a value of $A=0.12$ suitable for gravel and a shape exponent $m=2 / 3$, consistent with a number of studies (Dean and Darlymple, 2002). The beach profile extends from the position of top of the berm described by the beach width $B_{\mathrm{w}}$ $[L]$ and berm height $B_{\mathrm{h}}[L]$ (Fig. 3).

\section{Numerical model for ${ }^{10} \mathrm{Be}$ production in the shore platform}

The production of ${ }^{10} \mathrm{Be}$ fundamentally depends on how long the surface has been exposed and the rate at which material is removed through erosion (Gosse and Phillips, 2001). On a shore platform, exposure is modulated by topographic shielding, beach cover and water cover (Regard et al., 2012). Erosion of the shore platform may take place through gradual downwear processes or plucking and may not be spatially and temporally uniform (Dickson et al., 2013).

\subsection{Production of ${ }^{10} \mathrm{Be}$ in rock}

The concentration of ${ }^{10} \mathrm{Be} N$ [atoms $\cdot M^{-1}$ ] changes through time according to

$\frac{\mathrm{d} N}{\mathrm{~d} t}=P\left(h_{\mathrm{r}}\right)-\lambda N$

In Eq. (7), $P\left(h_{\mathrm{r}}\right)$ [atoms $\cdot M^{-1} \cdot T^{-1}$ ] is the depthdependent production rate of ${ }^{10} \mathrm{Be}, h_{\mathrm{r}}[L]$ is depth below the rock surface and $\lambda=4.99 \times 10^{-7}$ is the ${ }^{10} \mathrm{Be}$ radioactive decay constant (Chmeleff et al., 2010; Korschinek et al., 2010). The production of ${ }^{10} \mathrm{Be}$ in situ at and near the Earth surface declines exponentially with depth (self-shielding) as the cosmic ray flux attenuates (e.g. Gosse and Phillips, 2001; Balco et al., 2008; Mudd et al., 2016):

$P\left(h_{\mathrm{r}}\right)=\sum_{i} P_{\mathrm{s}}(i) e^{-\left(\frac{h_{\mathrm{r}}}{h^{*}(i)}\right)}$.

In Eq. (8), $P_{\mathrm{S}}$ [atoms $\cdot M^{-1} \cdot T^{-1}$ ] refers to the production rate at the rock surface for the production pathway $i .{ }^{10} \mathrm{Be}$ is predominantly produced by neutron spallation, with minor contribution from fast and slow muon interactions. Muogenic production penetrates much deeper into the Earth surface and therefore may source a significant part of observed ${ }^{10} \mathrm{Be}$ concentrations. Similar to West et al. (2014), we used a single exponential curve to integrate fast and slow muogenic production pathways (Braucher et al., 2011, 2013). The attenuation of spallation and muogenic reactions declines according to an attenuation length scale $h^{*}[L]$ that is dependent on the density of bedrock $\rho_{\mathrm{r}}\left[M \cdot L^{-3}\right]$ and a pathway-dependent attenuation factor $\Lambda\left[M \cdot L^{-2}\right]$ (for spallation $\Lambda=1600 \mathrm{~kg} \mathrm{~m}^{-2}$; and for muogenic production $\Lambda=42000 \mathrm{~kg} \mathrm{~m}^{-2}$ ):

$h^{*}(i)=\frac{\rho_{\mathrm{r}}}{\Lambda(i)}$.

\subsection{Topographic shielding}

Rock surfaces may be shielded from a portion of the incoming cosmic ray flux by local topography. At the coast, sea cliffs can block a significant portion of the sky and therefore partially shield the platform from cosmic rays. Typically, shielding factors can be quantified by field surveys (Dunne et al., 1999) or from topographic data (Codilean, 2006; Mudd et al., 2016). However, when the sea cliff is retreating, the amount of topographic shielding at a fixed location will change through time with increasing distance to the position of the cliff.

In order to model the influence of topographic shielding by the cliff on the accumulation of ${ }^{10} \mathrm{Be}$, we idealized that the cliff is vertical and of height $C_{H}[L]$ and assumed the cliff line to be straight in planform. For a given distance from the cliff $x_{\mathrm{c}}$, we defined the viewshed generated by the cliff as the angle in the sky $\theta$ from horizontal made by the top of the cliff in the azimuth direction $\phi$ for each observation $j$ :

$\theta(j)=\tan ^{-1}\left(\frac{C_{H} \cos \phi(j)}{x_{\mathrm{c}}}\right)$.

Following Dunne et al. (1999), a shielding factor $S_{\text {cliff }}$ is the ratio of cosmic ray flux given the viewshed $F$ to the maximum cosmic ray flux for an unobstructed flat surface $F_{\max }$ :

$S_{\text {cliff }}=\frac{F}{F_{\max }}=\frac{\Delta \phi}{2 \pi} \sum_{j=1}^{n} \sin ^{m+1} \theta(j)$,

where $n$ is the total number of viewshed observations that span the azimuth range $\phi=0-360^{\circ}$. A straight, vertical cliff 
line yields $S_{\text {cliff }}=0.5$ at $x_{\mathrm{c}}=0$ since $50 \%$ of the sky is obstructed.

Topographic shielding can also be modelled explicitly from a digital elevation model (DEM) following Codilean (2006). However these shielding values only apply to the current platform and cliff morphology. We compared Eq. (11) to shielding factors calculated from a DEM for shore platforms on the coast of East Sussex, UK (1 m resolution airborne lidar; data courtesy of Channel Coast Observatory; www.channelcoast.org; accessed 25 May 2014), using software published by Mudd et al. (2016, https://github.com/ LSDtopotools/LSDTopoTools_CRNBasinwide).

\subsection{Water shielding}

A shore platform is periodically exposed or submerged by the sea due to tides. The cosmic ray flux attenuates exponentially with water depth $h_{\mathrm{w}}[L]$ so that the production rate at the surface of the platform decreases according to

$P_{\mathrm{S}}(x, i)=P_{0}(i) e^{\frac{-h_{\mathrm{W}}(x)}{h_{\mathrm{W}}^{*}(i)}}$.

In Eq. (12), $P_{0}$ [atoms $\cdot M^{-1} \cdot T^{-1}$ ] is the reference production rate at the water surface, which is a function of latitude and altitude (e.g. Lal, 1991; Dunai, 2000; Stone, 2000; Desilets et al., 2006; Lifton et al., 2005). Equation (9) is used to calculate $z_{\mathrm{w}}^{*}$ by substituting water density $\rho_{\mathrm{w}}\left[M \cdot L^{-3}\right]$ for $\rho_{\mathrm{r}}$. Thus, the production by each pathway can be adjusted for attenuation in the water column; however, this adjustment depends on the tidal cycle at the site of interest.

\subsubsection{Tides}

Tides modify production in the platform by varying water depth $h_{\mathrm{w}}$ and intermittently submerging and exposing the platform subaerially. Relative to a scenario with no tidal variation, Regard et al. (2012) demonstrated that tides have a net effect to reduce ${ }^{10} \mathrm{Be}$ production in the upper intertidal platform due to periodic platform submergence that reduces the net cosmic ray flux received, while ${ }^{10} \mathrm{Be}$ production in the lower platform increases due to periodic exposure. Here we extended this analysis to explore the influence of tidal regime on ${ }^{10} \mathrm{Be}$ production.

Predictions of the tide are made as the sum of its harmonic constituents (e.g. Pugh and Woodworth, 2014):

$z_{\mathrm{W}}(t)=\sum_{n} H_{n} \cos \left(\sigma_{n} t-g_{n}\right)$.

In Eq. (13), $z_{\mathrm{w}}[L]$ is the elevation of the mean water surface, the subscript $n$ refers to the tidal constituent, $H_{n}$ is the amplitude $[L]$ of that constituent, $\sigma_{n}$ is the angular speed $\left[{ }^{\circ} \cdot T^{-1}\right]$ and $g_{n}$ is the phase lag [T]. Predictions of tidal elevation can be converted to water depth across the platform:

$h_{\mathrm{w}}(x, t)=\left\{\begin{array}{ll}z_{\mathrm{W}}(t)-z_{\mathrm{r}}(x, t) & \text { if } h_{\mathrm{w}} \geq 0 \\ 0 & \text { if } h_{\mathrm{w}}(t)<0\end{array}\right.$.
In Eq. (14), $z_{\mathrm{r}}[L]$ is the elevation of the platform surface; $h_{\mathrm{w}}$ must be positive (i.e. if the water level falls below the platform elevation, the water depth at this location is zero). Combining Eqs. (12) and (14), the production rate at the platform surface averaged over a tidal cycle $(T)$ can then be calculated as

$P_{\mathrm{S}}(x, i)=\frac{1}{T} \sum_{t=0}^{T} P_{0}(i) e^{\frac{-h_{\mathrm{W}}(x, t)}{h_{\mathrm{W}}^{*}(i)}}$.

We used Eqs. (13)-(15) to compare the distribution of platform surface production rates across the shore platform for hypothetical diurnal, mixed and semi-diurnal tidal regimes, generated using the tidal constituents listed in Table 1. These hypothetical tidal regimes were designed to cover a similar range in water levels across roughly a single lunar duration. We also compared the predicted $P_{\mathrm{s}}$ for a simple semi-diurnal tide to the effective production averaged over a full year of tidal records from the a tide gauge at Newhaven, East Sussex (available from www.channelcoast.org; accessed 2 October 2014).

\subsubsection{Relative sea level change}

For model experiments driven by steady-state retreat, RSL rise results in higher concentrations of ${ }^{10} \mathrm{Be}$ across the shore platform. This may seem counter-intuitive at first; however, less vertical downwear of the platform surface is required to maintain the steady-state profile during rising RSL and less material with high ${ }^{10} \mathrm{Be}$ concentrations is removed by downwear (Regard et al., 2012). In this study, we used constant rates of RSL change, since Holocene sea levels have been relatively stable over the last $7 \mathrm{kyr}$; however, for application to specific sites, RSL histories derived from local sedimentary records or regional crustal flexure models (e.g. Bradley et al., 2011) are recommended.

\section{Experimental setup}

We conducted a number of experiments to explore the influence of specific processes on the distribution of ${ }^{10} \mathrm{Be}$ across a shore platform. Here we describe the model setup used to investigate (i) the influence of platform erosion process; (ii) the influence of beach cover; (iii) the influence of tides; and (iv) the influence of transient profile evolution on the accumulation of ${ }^{10} \mathrm{Be}$ in the shore platform. Global parameters consistent across all experiments are listed in Table 2.

\subsection{Block removal processes}

To investigate the influence of block removal processes, we evolved a steady-state profile with a fixed average slope $\alpha=1 / 100$ consisting of offset horizontal surfaces akin to horizontal bedding planes. The separation between surfaces was varied from $0 \mathrm{~m}$ (uniform sloped platform, downwear 
Table 1. Tidal constituents used to generate synthetic tides to explore variation in ${ }^{10} \mathrm{Be}$ production under different tidal regimes.

\begin{tabular}{lrr|rr|rr|rr|rr|rr|r|r}
\hline Tidal & \multicolumn{2}{c|}{ Tide A } & \multicolumn{2}{c|}{ Tide B } & \multicolumn{2}{c|}{ Tide C } & \multicolumn{2}{c|}{ Tide D } & \multicolumn{2}{c|}{ Tide E } & \multicolumn{2}{c}{ Tide F } \\
\cline { 2 - 13 } Constituent & $H_{n}$ & $\sigma_{n}$ & $H_{n}$ & $\sigma_{n}$ & $H_{n}$ & $\sigma_{n}$ & $H_{n}$ & $\sigma_{n}$ & $H_{n}$ & $\sigma_{n}$ & $H_{n}$ & $\sigma_{n}$ \\
\hline$K 1$ & 2.5 & 15.041 & - & - & 0.7 & 15.041 & 2.0 & 15.041 & - & - & 0.4 & 15.041 \\
$K 2$ & - & - & - & - & - & - & - & - & - & - & 0.1 & 30.082 \\
$M 1$ & - & - & - & - & - & - & - & - & - & - & 0.1 & 14.492 \\
$M 2$ & - & - & 2.5 & 28.984 & 1.8 & 28.984 & - & - & 2.0 & 28.984 & 1.5 & 28.984 \\
$N 2$ & - & - & - & - & - & - & - & - & 0.5 & 28.440 & 0.5 & 28.440 \\
$O 1$ & - & - & - & - & - & - & 0.5 & 13.943 & - & - & 0.2 & 13.043 \\
\hline
\end{tabular}

Table 2. Global parameters used in modelling ${ }^{10} \mathrm{Be}$ accumulation in a shore platform.

\begin{tabular}{lll}
\hline Description & Symbol & Value \\
\hline Acceleration due to gravity & $g$ & $9.81 \mathrm{~m} \mathrm{~s}^{-2}$ \\
Density of seawater & $\rho_{\mathrm{W}}$ & $1025 \mathrm{~kg} \mathrm{~m}^{-3}$ \\
Density of rock & $\rho_{\mathrm{r}}$ & $1800 \mathrm{~kg} \mathrm{~m}^{-3}$ \\
Surface production rate (spallogenic) & $P_{0}(s)$ & 4.0 atoms g \\
Surface production rate (muogenic) & $P_{0}(\mu)$ & $0.028 \mathrm{atoms} \mathrm{g}^{-1} \mathrm{yr}^{-1}$ \\
${ }^{10}$ Be decay constant & $\lambda$ & $4.99 \times 10^{-7}$ \\
Attenuation rate (spallogenic) & $\Lambda_{\mathrm{S}}$ & $1600 \mathrm{~kg} \mathrm{~m}^{-2}$ \\
Attenuation rate (muogenic) & $\Lambda_{\mu}$ & $42000 \mathrm{~kg} \mathrm{~m}^{-2}$ \\
\hline
\end{tabular}

inferred to be by abrasion) to $0.8 \mathrm{~m}$. Steps in the steadystate profile were allowed to migrate landward through time in concert with a prescribed constant cliff retreat rate of $\epsilon=0.1 \mathrm{~m} \mathrm{yr}^{-1}$. RSL was held constant, and a diurnal tide with $H_{n}=1.0 \mathrm{~m}$ was used.

\subsection{Beach cover}

Beaches cover the shore platforms in the near-shore zone, which partially shields the platform from cosmic rays and, as a result, reduces ${ }^{10} \mathrm{Be}$ production in the platform surface. The presence of beach cover may not be consistent but will depend on the supply of material from the adjacent cliffs, the supply and removal of sediment due to both alongshore and cross-shore sediment transport, and the rate at which beach material is physically and chemically weathered. We conducted a series of experiments designed to investigate the influence of beach cover on the accumulation of ${ }^{10} \mathrm{Be}$ on a shore platform. Firstly, we considered a simple case where beach morphology is held constant through time and explore the influence that constant beach width has $\left(B_{\mathrm{w}}=0\right.$, $10,20,50,100 \mathrm{~m}$ ) on the concentration of ${ }^{10} \mathrm{Be}$ in the shore platform. Secondly, we considered the condition that beach width may vary through time, with beach width varying as a sinusoidal function over decadal timescales (wavelength: 100 years), with an average $B_{\mathrm{w}}=50 \mathrm{~m}$ and amplitude of $30 \mathrm{~m}$. Thirdly, we considered the condition that beaches may be lost through time, as beach material is transported away more rapidly than it is supplied by alongshore transport and cliff erosion. These scenarios all evolved the shore profile by steady-state retreat with a cliff retreat rate of $\epsilon=0.1 \mathrm{~m} \mathrm{yr}^{-1}$. RSL was held constant and a diurnal tide with $H_{n}=1.0 \mathrm{~m}$ was used.

\subsection{Steady-state and transient shore platform evolution}

Previous studies have assumed that shore platform evolution proceeds in steady state such that a constant shore profile morphology is translated landward through time and tracks the trajectory of RSL change (Regard et al., 2012). Here, we explored the influence of RSL rise on shore platform morphology and the resulting distribution of ${ }^{10} \mathrm{Be}$ across shore platforms with RoBoCoP (see Sect. 2.2). We compared the results of dynamic shore platform evolution experiments to those of steady-state shore profile retreat to investigate the influence that the assumption steady retreat may have on the accumulation of ${ }^{10} \mathrm{Be}$ and our ability to interpret rates of cliff retreat. The initial and boundary conditions for the model were held constant (see Table 3). The model is initialized with a sloped platform profile and forward modelled for $10 \mathrm{kyr}$. In our first set of experiments, we held RSL constant, whilst during the second set of experiments RSL rose at a constant rate $\left(0.5 \mathrm{~mm} \mathrm{yr}^{-1}\right)$. RSL rise is known from previous experiments to influence the rate of cliff retreat and how it changes through time, the morphology of the platform, and the amount and distribution of platform downwear (Trenhaile, 2000; Walkden and Hall, 2005). We compared the resultant ${ }^{10} \mathrm{Be}$ concentrations to predictions that assume 
Table 3. Parameters used in modelling transient shore platform evolution.

\begin{tabular}{lll}
\hline Description & Symbol & Value \\
\hline Initial platform gradient & $\alpha$ & $0.1 \mathrm{~m} \mathrm{~m}^{-1}$ \\
Offshore wave height & $H_{0}$ & $1.0 \mathrm{~m}$ \\
Wave period & $T$ & $6 \mathrm{~s}$ \\
Resistance coefficient & $K$ & $10^{-4} \mathrm{~m} \mathrm{~s} \mathrm{~kg}^{-1}$ \\
Wave energy dissipation & $k$ & 0.2 (dimensionless) \\
coefficient & & \\
Tidal amplitude & $H_{n}$ & $1.0 \mathrm{~m}$ \\
Angular speed & $\sigma_{n}$ & $28.984^{\circ} \mathrm{h}^{-1}$ \\
\hline
\end{tabular}

steady-state retreat in order to determine whether this assumption allows the estimation of average transient retreat rates.

\section{Results}

\subsection{Topographic shielding}

The topographic shielding scaling factor $S_{\mathrm{T}}$ is predicted to have a value of 0.5 immediately adjacent to the cliff, increasing non-linearly with distance from the cliff (Fig. 4a). Cliff height principally controls the rate at which $S_{\mathrm{T}}$ increase, such that taller cliffs result in a greater degree of shielding for a greater distance offshore. $S_{\mathrm{T}}$ approaches unity asymptotically by $x_{\mathrm{c}} \approx 4 \cdot C_{H}$; there is little influence of the cliff on ${ }^{10} \mathrm{Be}$ production beyond. Our approach (Eq. 11) assumes a straight cliff line with constant cliff height. We compared this approach to the distribution of topographic shielding factors modelled for a real stretch of coastline in East Sussex, UK, following Codilean (2006) (Fig. 4b). Again, these distributed $S_{\mathrm{T}}$ values are smallest immediately adjacent to the cliff $(0.5)$ and increase non-linearly with distance across the shore platform. The values calculated from the DEM are in good agreement with Eq. (11) as demonstrated by three example transects, each with different cliff heights (Fig. 4c). Differences between observed and model $S_{\mathrm{T}}$ values are due to variation in the gradient of the cliff face and the planform geometry of the cliff line. Since it is unlikely in most settings to have information on how $C_{H}$ and the planform geometry may have changed through time, we used Eq. (11) to represent topographic shielding, assuming constant $C_{H}$.

\subsection{Water shielding by tides}

Variation in water level on hourly timescales due to tides modifies the cosmic ray flux delivered to the platform. The tidal regime at a site may influence the distribution of ${ }^{10} \mathrm{Be}$ production across a shore platform, and so we explored the effects of hypothetical diurnal, mixed and semi-diurnal tidal regimes (Fig. 5a-f) on ${ }^{10} \mathrm{Be}$ concentrations. The tidal constituents used to model these are shown in Table 1. Figure $5 \mathrm{~g}$
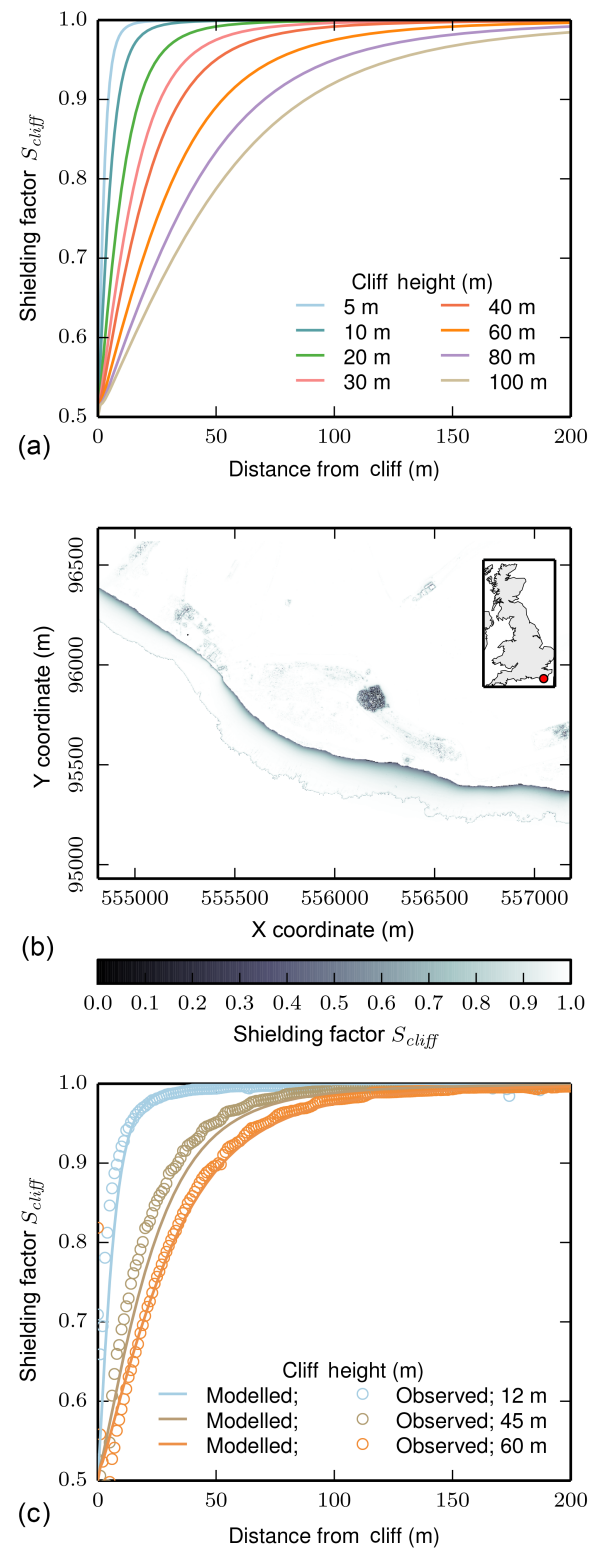

Figure 4. Topographic shielding due to sea cliff. (a) Analytical model for topographic shielding on a shore platform as a function of distance from cliff measured according to Eq. (11) for cliff heights ranging from 5 to $100 \mathrm{~m}$. (b) Example map of the distribution of topographic shielding across a shore platform at Beachy Head, East Sussex, UK. (c) Comparison of Eq. (11) to values measured using distributed shielding routines (Codilean, 2006; Mudd et al., 2016).

shows the distribution of relative spallation production $P_{\mathrm{S}} / P_{0}$ across a planar platform defined by $\alpha=1 / 100$ under these six different hypothetical tidal regimes. Tides act to reduce the production in the near-shore-upper-intertidal zone due to periodic submergence of the upper platform, whilst production in the lower intertidal zone is increased due to periodic exposure of the platform. Simple diurnal/semi-diurnal tides show the strongest modification of ${ }^{10} \mathrm{Be}$ production ac- 

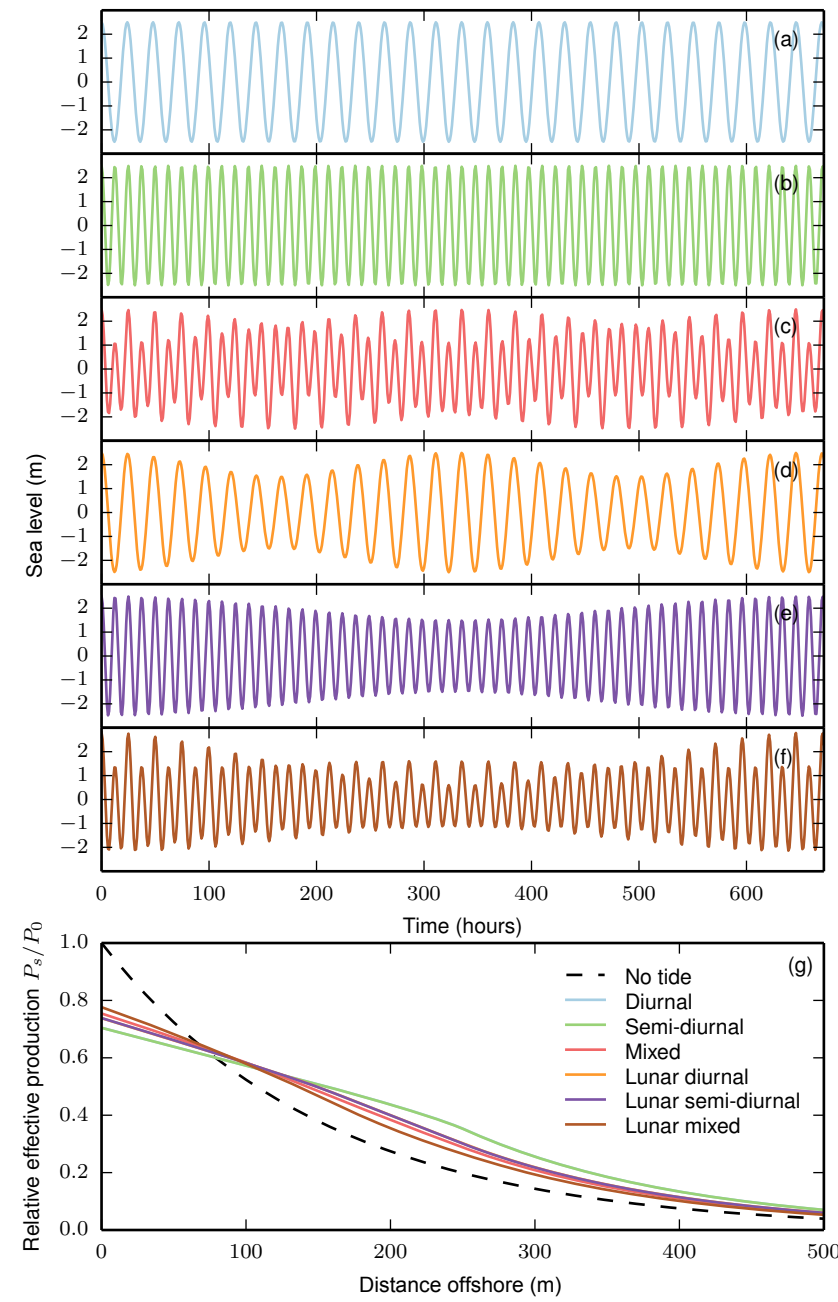

Figure 5. Influence of tidal regime on the distribution of ${ }^{10} \mathrm{Be}$ production across a shore platform. (a-f) Tidal water levels over a 28day period for the hypothetical tidal regimes explored here (see Table 1). (g) Production rates relative to the case where there is no water shielding $\left(h_{\mathrm{w}}=0\right)$ as a function of distance offshore on a shore platform with gradient $\alpha=1 / 100$ for the different tidal regimes plotted in panels (b-g).

cording to our experiments, but this is strongly dependent on $H_{n}$ for the additional constituents. Different tidal regimes may result in differences in the production of ${ }^{10} \mathrm{Be}$ across the coastal platform, and therefore it is important to consider the tidal regime at a particular site to model ${ }^{10} \mathrm{Be}$ production in the platform.

Figure 6 shows the distribution of the effective production rate at the platform surface for purely diurnal tides with an amplitude of $2.4 \mathrm{~m}$, compared to the tide gauge water level record at Newhaven, East Sussex, UK. Incorporation of a tidal record with the full range of harmonic components dampens production very slightly in the near-shore region and slightly increases production further offshore relative to a simple semi-diurnal tide model. These differences do not sig-

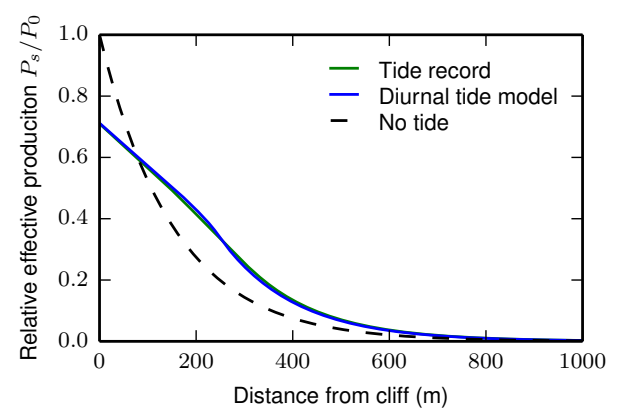

Figure 6. Distribution of ${ }^{10} \mathrm{Be}$ production across a shore platform with gradient $\alpha=1 / 100$ for a simple diurnal tide model with amplitude $2.4 \mathrm{~m}$ and for real tide data from Newhaven, East Sussex, UK. Note there is very little difference in production between the two, suggesting that a diurnal model with representative amplitude is sufficient for the purpose of modelling ${ }^{10} \mathrm{Be}$ production.

nificantly influence ${ }^{10} \mathrm{Be}$ production. A simple diurnal/semidiurnal tide model with a single representative tidal amplitude is appropriate at some sites.

\subsection{Block removal processes}

Model results of the migration of bedrock steps due to block removal processes across a shore platform that evolve through steady-state retreat are shown in Fig. 7a for a range of step sizes. The landward migration of steps results in the sudden exposure of platform that was previously the depth of the step size below the platform surface. Since ${ }^{10} \mathrm{Be}$ production rates decline exponentially with depth into the rock (Eq. 8), block removal unearths rock with significantly lower concentration, resulting in sudden drops in ${ }^{10} \mathrm{Be}$ concentration with distance across the platform (Fig. 7b). However, the flat-topped steps are subject to no vertical downwear in these simulations and so they continue to accumulate ${ }^{10} \mathrm{Be}$ such that, between bedrock steps, concentrations increase with distance from the cliff. The result is a saw-toothed distribution of concentrations, superimposed on the "humped" distribution expected when there is no block removal. The magnitude and wavelength of the variability in concentrations is controlled by the size and frequency of the bedrock steps.

\subsection{Beach cover control on ${ }^{10} \mathrm{Be}$ concentrations}

Beaches were represented by a Bruun profile (Eq. 6) that extends seaward from a prescribed beach width and berm height (Fig. 3). Beach cover may not be constant through time. We explored the influence of beach width, variable beach width and declining beach width on shore platform ${ }^{10} \mathrm{Be}$ concentrations. 


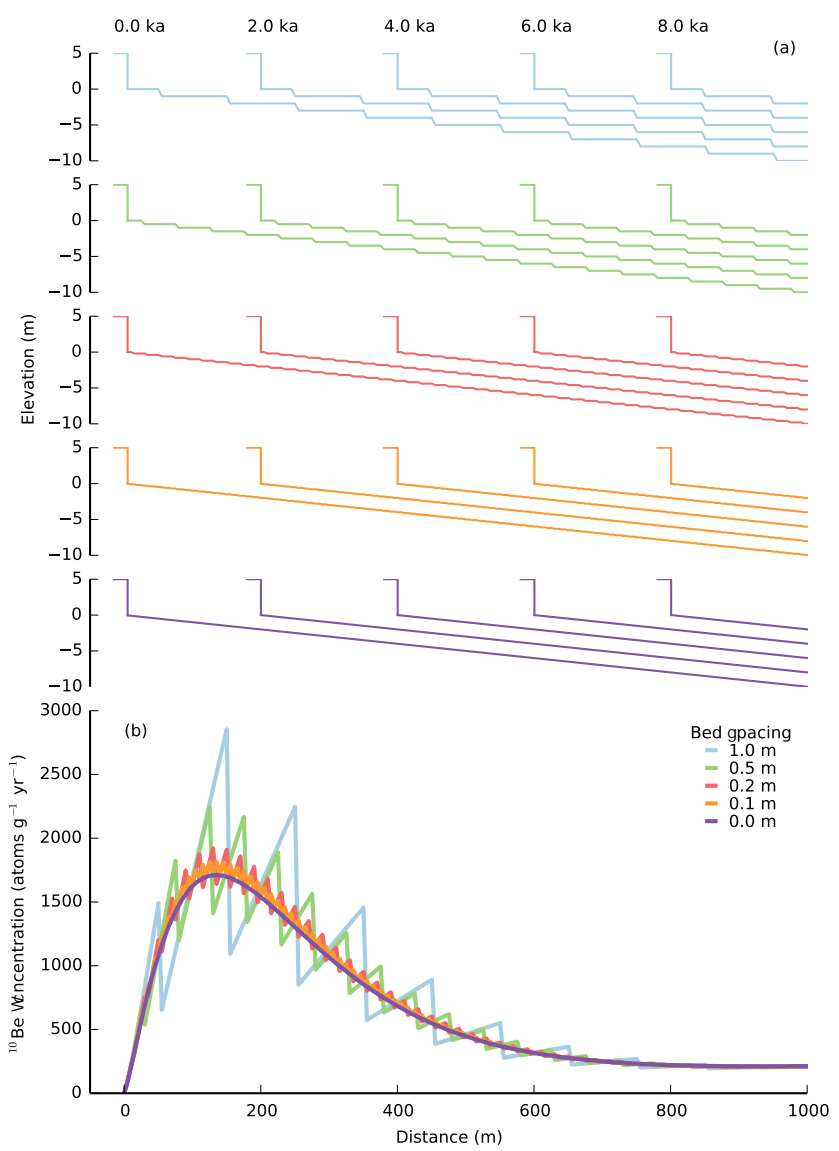

Figure 7. (a) Evolution of stepped shore platform profiles over $10 \mathrm{kyr}$ for step sizes (bedding thickness) up to $1 \mathrm{~m}$. (b) Corresponding distribution of ${ }^{10} \mathrm{Be}$ as a function of step size. Large steps due to block removal processes result in a saw-toothed distribution superimposed on the expected humped distribution. Variability in the platform surface concentration increases with step size.

\subsubsection{Influence of beach cover}

Beach cover is expected to partially shield the near-shore platform from cosmic rays and therefore reduce concentrations of ${ }^{10} \mathrm{Be}$ in the platform surface. Wider beaches should result in lower ${ }^{10} \mathrm{Be}$ concentrations. We ran model experiments with different values of $B_{\mathrm{w}}$, which was held constant for the duration of each experiment (Fig. 8a). The predicted distributions of ${ }^{10} \mathrm{Be}$ concentrations increase and then decrease in the offshore direction, and the magnitude of the "hump" is reduced when beaches are wider (Fig. 8b). The position of the peak with respect to the cliff moves offshore as production in the near-shore zone is reduced by beach cover. The black line corresponds to the scenario with no beach cover. The concentrations of ${ }^{10} \mathrm{Be}$ at the platform surface decrease in a linear fashion with wider beaches (Fig. 9), to the extent that a $50 \mathrm{~m}$ wide beach results in an $18 \%$ reduction in the magnitude of the ${ }^{10} \mathrm{Be}$ concentrations. If not accounted for, this would lead to over-prediction of cliff retreat
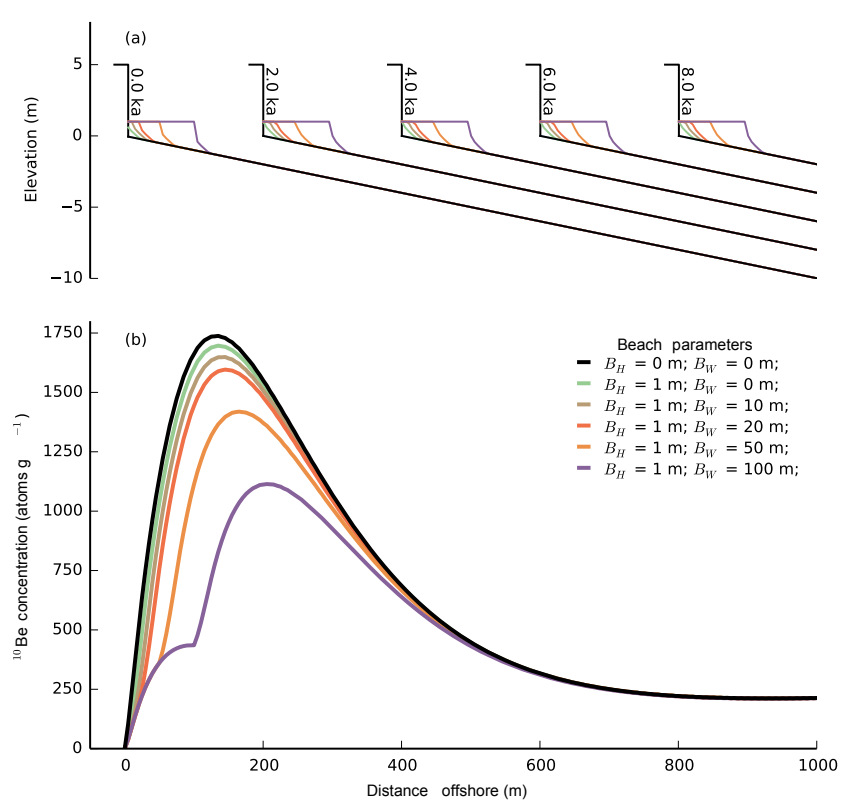

Figure 8. (a) Evolution of shore platform profiles over $10 \mathrm{kyr}$ with constant beach cover in the near-shore zone described by a Bruun profile (Eq. 6). (b) Corresponding distribution of ${ }^{10} \mathrm{Be}$ as a function of beach width. Beach cover reduces the concentrations of ${ }^{10} \mathrm{Be}$ in the platform surface, and wider beaches result in lower ${ }^{10} \mathrm{Be}$ concentrations and cause the position of the peak in concentrations to be further out from the cliff. Note that quite extreme beach cover $B_{\mathrm{W}} \geqslant 50 \mathrm{~m}$ is required to significantly $(\geqslant 15 \%)$ reduce platform ${ }^{10}$ Be concentrations.

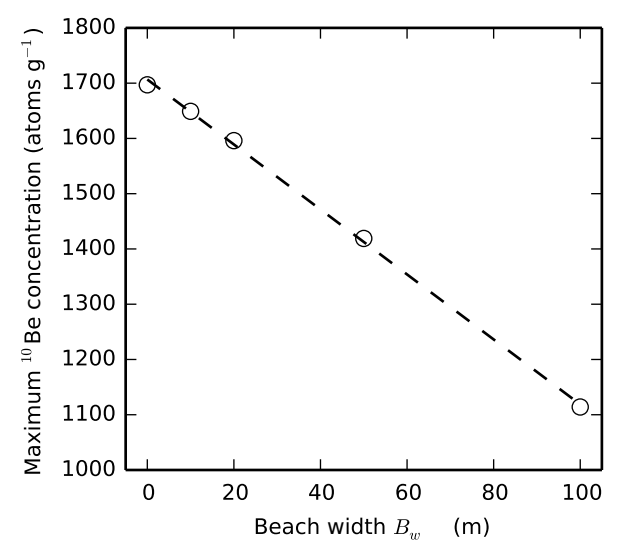

Figure 9. Reduction in the magnitude of peak concentration of ${ }^{10} \mathrm{Be}$ with increasing beach width. Black symbols show the peak concentrations taken from Fig. 8. The relationship is approximately linear as shown by the dashed line fit by least squares regression. Note that quite extreme beach cover $B_{\mathrm{W}} \geqslant 50 \mathrm{~m}$ is required to significantly $(\geqslant 15 \%)$ reduce platform ${ }^{10} \mathrm{Be}$ concentrations.

rates when inverting measured ${ }^{10} \mathrm{Be}$ concentrations, since, in the absence of beaches, lower concentrations of ${ }^{10} \mathrm{Be}$ suggest faster cliff retreat rates (Regard et al., 2012). 

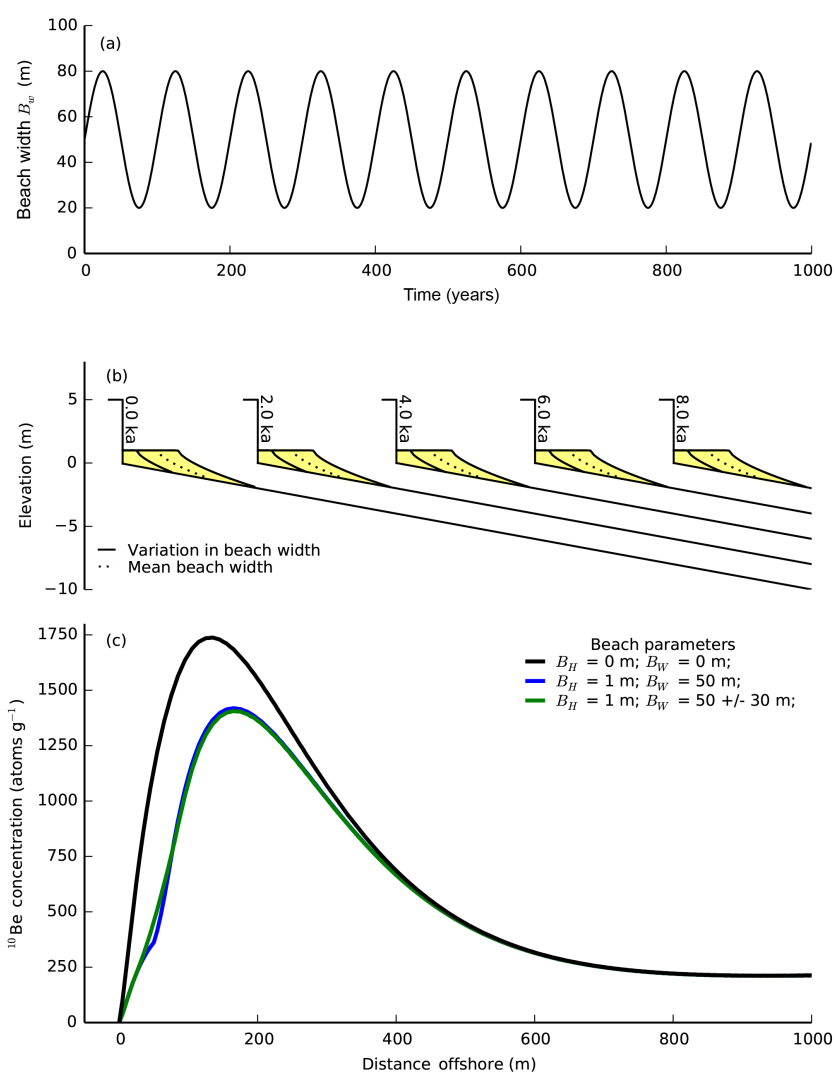

Figure 10. (a) Variation in beach width through time modelled as a sinusoidal function with a beach width $B_{\mathrm{W}}=50 \pm 30 \mathrm{~m}$ and wavelength 100 years. (b) Evolution of shore platform profiles over $10 \mathrm{kyr}$ with variable beach cover in the near-shore zone described by a Bruun profile (Eq. 6). (c) Corresponding distribution of ${ }^{10} \mathrm{Be}$ for the case with no beach cover, fixed $B_{\mathrm{W}}=50 \mathrm{~m}$, and variable beach cover. Note that there is little difference in ${ }^{10} \mathrm{Be}$ concentrations between a constant beach cover and variable beach cover.

\subsubsection{Influence of variable beach cover}

Beach cover may not be constant through time; however, there is rarely any evidence available revealing how beaches may have changed during the Holocene on eroding coastlines, since eroded material tends to be removed. We explored how variable beach cover modifies ${ }^{10} \mathrm{Be}$ concentrations by modelling $B_{\mathrm{w}}$ through time as a sinusoidal function with wavelength 100 years and amplitude $30 \mathrm{~m}$ about an average of $B_{\mathrm{w}}=50 \mathrm{~m}$ (Fig. 10a). Thus, the beach progrades and regresses every 100 years, maintaining an equilibrium beach profile (Fig. 10b). The resultant distribution of ${ }^{10} \mathrm{Be}$ concentrations are compared to simulations with no beach cover and a constant $B_{\mathrm{w}}=50 \mathrm{~m}$ (Fig. 10c). We found that there is very little difference in ${ }^{10} \mathrm{Be}$ concentrations between a constant and variable beach width scenario.

We also explored scenarios in which beach cover was reduced through time. Figure 11 shows the morphological evolution and concentrations of ${ }^{10} \mathrm{Be}$ in the shore platform sur-
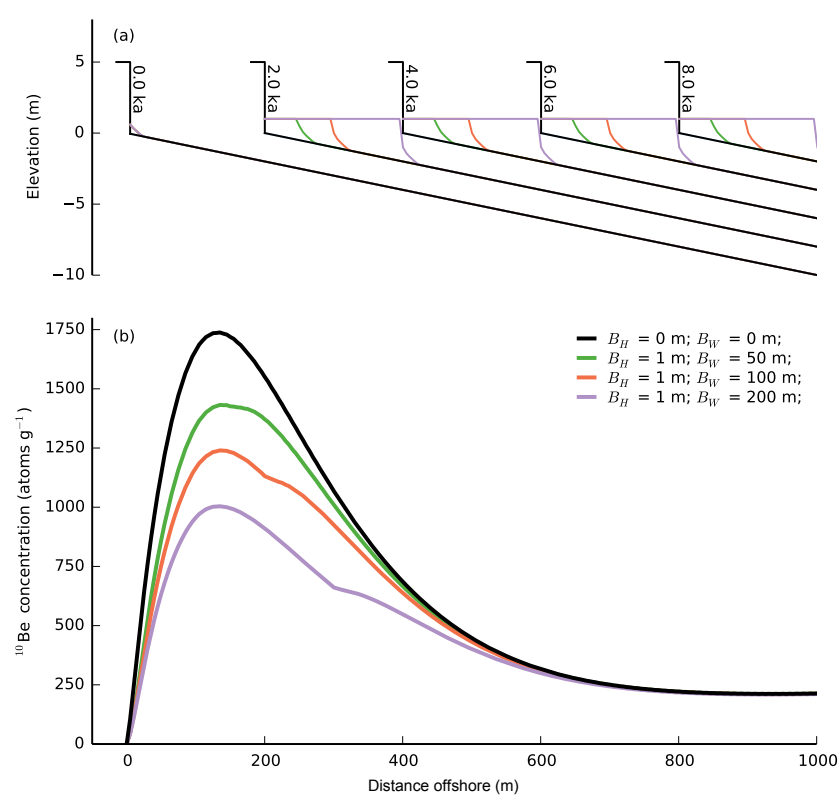

Figure 11. (a) Evolution of shore platform profiles over $10 \mathrm{kyr}$ with variable beach cover in the near-shore zone described by a Bruun profile (Eq. 6). Beach width reduces to $B_{\mathrm{W}}=0 \mathrm{~m}$ during the last 1000 years of the model runs. (b) Corresponding distribution of ${ }^{10} \mathrm{Be}$ for the case with no beach cover and thinning beaches during the last 100 years. The presence of beaches that disappeared over the last 1000 years would result in lower concentrations of ${ }^{10} \mathrm{Be}$ in the platform surface.

face predicted for the condition where beaches have thinned from a constant width of 50,100 or $200 \mathrm{~m}$ over the last 1000 years. The thinning of beaches and thus the presence of more beach cover in the past reduces the expected concentrations of ${ }^{10} \mathrm{Be}$ in the shore platform. This will result in over-prediction of cliff retreat rates when not accounted for, since platform ${ }^{10} \mathrm{Be}$ concentrations will be lower, as otherwise they are associated with more rapid rates of cliff retreat.

\subsection{Transient shore platform evolution}

\subsubsection{Constant sea level}

We modelled the evolution of a shore profile given constant RSL and the consequential concentrations of ${ }^{10} \mathrm{Be}$ across the modelled shore profile. The gradient of the shore platform decreases through time, as the platform widens (Fig. 12a). A stepped platform emerges with the step at the lower tidal limit, reflected by a downward step in ${ }^{10} \mathrm{Be}$ concentrations on the shore platform (Fig. 12b). Wave energy attenuation increases as the platform widens such that cliff retreat rates decline as the model simulation proceeds (Fig. 12c). Reduction in the mean gradient of the platform is shown in Fig. 12d. The distribution of ${ }^{10} \mathrm{Be}$ concentrations is humped, similar in form to predictions of a steady-state retreat model (Regard 

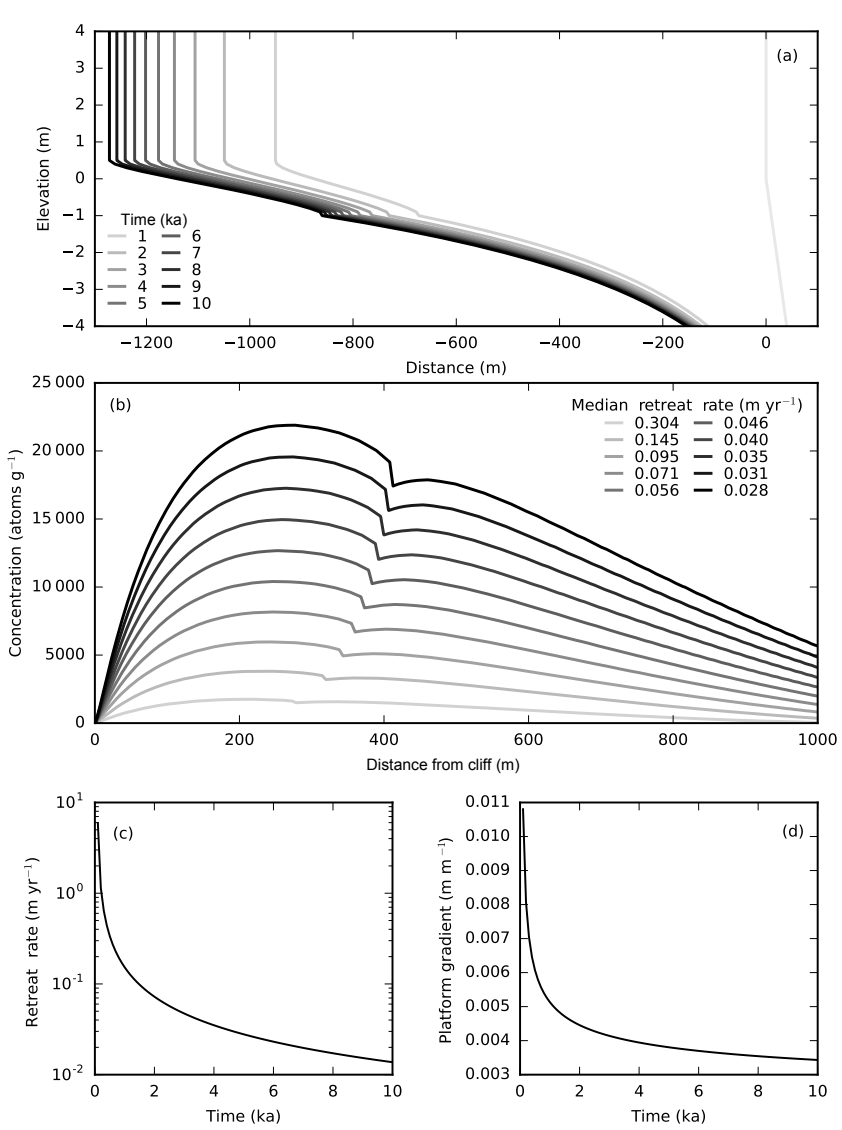

Figure 12. Transient simulations of shore profile evolution and ${ }^{10} \mathrm{Be}$ concentrations for the case with no sea level rise. (a) Evolution of shore platform profiles over $10 \mathrm{kyr}$ driven by RoBoCoP (colourcoded in $1 \mathrm{kyr}$ interval). (b) Corresponding ${ }^{10} \mathrm{Be}$ concentration predictions, normalized to the position of the cliff (colour coding also corresponds to the median retreat rates listed). Retreat rates are initially rapid and decline through time (c) and show a humped distribution, similar to steady-state model predictions. The magnitude of the hump increases through time as the length of exposure increases and cliff retreat rates and platform downwear rates decline, resulting in a decrease in platform gradient through time (d).

et al., 2012). The magnitude of the hump increases through time, as cliff retreat rates slow.

In order to compare results directly, we then ran simulations where the morphology evolved in steady state (cliff retreat rate was held constant, using the median values reported in Fig. 12b); platform gradient was taken as the instantaneous average platform gradient in each profile in Fig. 12a (measured between platform elevations $z=0.5$ and $z=-1 \mathrm{~m}$ ). These simulations ran for long enough that $1000 \mathrm{~m}$ of cliff retreat had occurred. The comparison of the distribution of ${ }^{10} \mathrm{Be}$ concentrations between the transient (solid lines) and steady-state (dashed lines) model runs is shown in Fig. 13a, shaded by their retreat rate as listed in the legend in Fig. 12b. The magnitude of the peak in concentrations were in this case similar between transient and steady-state simulations
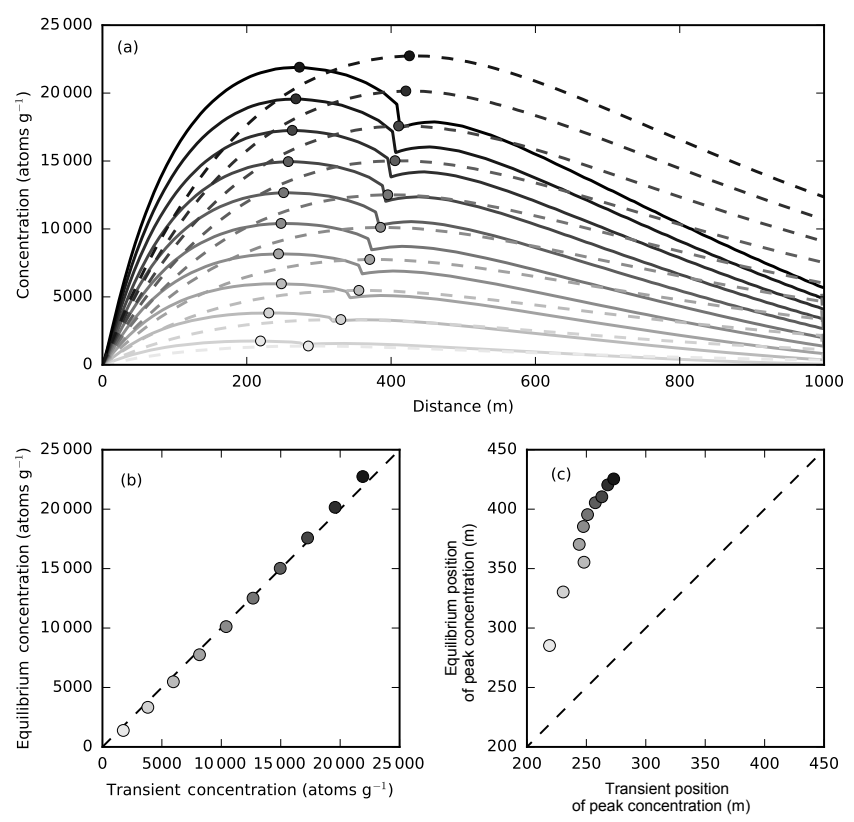

Figure 13. Comparison of transient simulations from Fig. 12 to predictions assuming steady-state profile retreat. Steady-state models are run with the constant retreat rate taken as the median values in the transient simulations (Fig. 12). Colour coding corresponds to the median retreat rates reported in Fig. $12 \mathrm{~b}$ and the instantaneous mean platform gradient for each profile in Fig. 12a. (a) Distribution of ${ }^{10} \mathrm{Be}$ concentration predictions. The magnitude of the hump is similar as shown in panel (b), but the location of the peak in concentration is further offshore when steady-state retreat is assumed, as also shown in panel (c).

(Fig. 13b); however, the position of the peak was further offshore in the steady-state simulations (Fig. 13c).

\subsubsection{Rising relative sea level}

We modelled the transient evolution of a shore profile and ${ }^{10} \mathrm{Be}$ concentrations with a sea level rise of $0.5 \mathrm{~mm} \mathrm{yr}^{-1}$ (Fig. 14). The shore platform evolves rapidly to form a lowgradient shore platform ramp (Fig. 14a). The elevation of the platform-cliff junction increases through time and tracks the high-tide level, superimposed on the trajectory of RSL rise. Cliff retreat rates are initially rapid and decline towards a constant rate of $0.32 \mathrm{~cm} \mathrm{yr}^{-1}$ (Fig. 14c). Having attained a constant rate of cliff retreat, concentrations of ${ }^{10} \mathrm{Be}$ in the platform as a function of distance from the cliff are constant, consistent with the concept of steady-state morphological retreat. Due to low platform gradients, and the absence of significant platform downwear below the intertidal zone, concentrations of ${ }^{10} \mathrm{Be}$ continue to increase offshore, and so no "hump" in concentrations is observed.

We compared these predictions to those of a steady-state retreat model with the cliff retreat rate $\left(32 \mathrm{~cm} \mathrm{yr}^{-1}\right)$ and platform gradient $(1 / 500)$ observed in the above transient exper- 

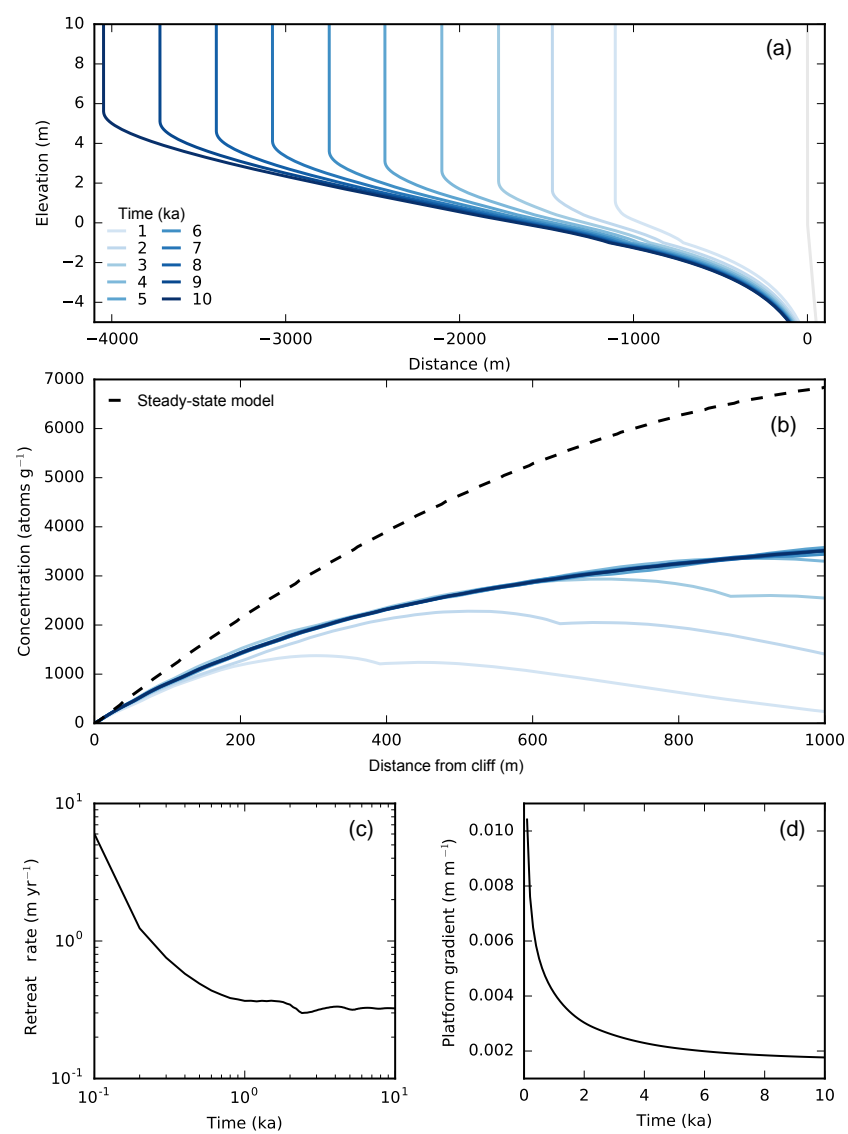

Figure 14. Transient simulations of shore profile evolution and ${ }^{10} \mathrm{Be}$ concentrations for the case with $0.5 \mathrm{~mm} \mathrm{yr}^{-1}$ relative sea level rise. (a) Evolution of shore platform profiles over $10 \mathrm{kyr}$ driven by RoBoCoP (1 kyr interval). Retreat rates are initially rapid but steady to $32 \mathrm{~cm} \mathrm{yr}^{-1}$ after $1 \mathrm{kyr}$. Platform gradient declines through time. (b) Corresponding ${ }^{10} \mathrm{Be}$ concentration predictions, normalized to the position of the cliff. Note that ${ }^{10} \mathrm{Be}$ concentrations are consistent with distance from the cliff throughout the model runs and consistent with steady-state morphological retreat. The dashed line shows the predictions of a steady-state morphological model with retreat rate of $32 \mathrm{~cm} \mathrm{yr}^{-1}$, platform gradient of $1 / 500$ and relative sea level rise rate of $0.5 \mathrm{~mm} \mathrm{yr}^{-1}$. Steady-state model predicts higher concentrations than transient simulations by about a factor of 2 .

iment. The results are plotted as the dashed line in Fig. 14b. The steady-state retreat model similarly predicts concentrations that increase across the entire shore platform due to minimal platform downwear in the presence of sea level rise. However, the steady-state model predicts significantly higher concentrations of ${ }^{10} \mathrm{Be}$ across the shore platform, by about a factor of 2, due to differences in the distribution of downwear between the two models. In the transient model runs, the amount of platform downwear declines exponentially with water depth, leading to rapid erosion in the mid to upper intertidal zone, where ${ }^{10} \mathrm{Be}$ production rates are most rapid. This is evidenced by the concave-up shore profile nearest to the cliff. Therefore, not only does more downwear oc- cur on the upper part of the transient profile, but as a result, water depths increase more quickly offshore, and increased water shielding reduces ${ }^{10} \mathrm{Be}$ production and concentrations on the shore platform as a whole. Thus, if we were to assume steady-state retreat and a planar shore platform in a setting where there is more platform downwear in the intertidal zone, we are likely to overestimate retreat rates since ${ }^{10} \mathrm{Be}$ concentrations will be lower than expected for a given retreat rate.

\section{Discussion}

We have identified that concentrations of ${ }^{10} \mathrm{Be}$ on shore platforms are sensitive to (i) shielding by cliffs; (ii) the type of process (gradual downwear vs. quarrying); (iii) the tidal regime; (iv) the nature of beach cover and how it has changed through time; and (v) the style (steady state vs. transient) by which the platform evolves, particularly in the face of RSL change.

Nevertheless, these results demonstrate that there is great potential for ${ }^{10} \mathrm{Be}$ measurements to provide first-order estimates of long-term rates of sea cliff retreat (Regard et al., 2012; Rogers et al., 2012; Choi et al., 2012; Hurst et al., 2016). Quantifying these factors, and how they may have changed over the millennial timescales required to accumulate significant ${ }^{10} \mathrm{Be}$ concentrations, may not always be possible. Some of these factors can be accounted for explicitly in site-specific studies, such as cliff shielding, given the height of the modern cliff; tides, informed by nearby tide gauges; and RSL change, from proxy records or glacio-isostatic adjustment models. We are still required to assume that these factors have not changed through time; it is always necessary, to some extent, to extrapolate the modern coastal configuration back into the past. We have little or no information about the paleaotopography offshore from a modern cliff. Observations of beach cover can be made from historical data (e.g. Dornbusch et al., 2008) but are limited to the length of the historical record (ca. 150 years maximum) and may be influenced by human intervention at the coast. Many of these factors act to reduce predictions of ${ }^{10} \mathrm{Be}$ in the shore platform, but maintain the overall "humped" shape of the distribution. It appears not possible to distinguish from the ${ }^{10} \mathrm{Be}$ concentrations what the history of beach cover is if it is different from present. It may be possible to identify when a platform is evolving transiently (see below). If factors that reduce ${ }^{10} \mathrm{Be}$ concentrations were not considered, then we would expect to over-predict rates of cliff retreat. Consequently, cliff retreat rates derived from ${ }^{10} \mathrm{Be}$ concentrations might be considered maximum estimates. Below, we discuss some of these issues further in the context of quantifying long-term rates of cliff retreat. 


\subsection{Block removal processes}

Our simplified experiments demonstrate that where block removal processes are an important process for platform evolution, the expected distribution of ${ }^{10} \mathrm{Be}$ becomes more variable, with higher frequency variation superimposed on the expected "humped" distribution (Fig. 7). Consequently, ${ }^{10} \mathrm{Be}$ concentrations can still reveal rates of cliff retreat, but a careful sampling strategy will be required to account for block removal processes. Observations of platform erosion process should be made when sampling, and the size of steps or blocks will be important to record. Where available, information on the rate at which steps migrate and blocks are removed will help to inform sampling and interpretation (e.g. Dornbusch and Robinson, 2011; Naylor et al., 2016). Measuring ${ }^{10} \mathrm{Be}$ concentrations on shore platforms where block removal processes are dominant may allow the rate of step migration to be determined in the presence of large bedrock steps (Fig. 7). This will require high-density sampling, focused on an individual bedrock step surface. If sampling on a platform with a stepped profile, data on the size of steps should be recorded and the position of samples relative to steps will also be important.

\subsection{Transient shore platform development}

Previous studies had assumed that steady-state profile retreat was an adequate description of the morphological evolution of the shore platform in order to predict cliff retreat rates from ${ }^{10} \mathrm{Be}$ concentrations in the shore platform over millennial timescales (Regard et al., 2012). Dynamic shore profile evolution models (e.g. Sunamura, 1992; Anderson et al., 1999; Trenhaile, 2000; Walkden and Hall, 2005; Matsumoto et al., 2016) predict that coasts tend towards steady state, whereby rapid cliff retreat widens shore platforms and the resultant increased wave energy dissipation reduces cliff retreat rates and increases erosion of the shore platform. We coupled predictions of ${ }^{10} \mathrm{Be}$ production to a dynamic shore profile evolution model (RoBoCoP; see Sect. 2.2) in scenarios with (i) constant RSL, such that cliff retreat rates gradually reduced through time due to widening of the shore platform, and (ii) rising RSL, such that cliff retreat rates tended to a constant rate in time.

In scenario (i) the concentrations of ${ }^{10} \mathrm{Be}$ on the shore platform increased through time as cliff retreat rates declined (Fig. 12). Comparison to predictions of steady-state profile retreat (Fig. 13) revealed that the position of the peak in ${ }^{10} \mathrm{Be}$ concentrations was further offshore when assuming steadystate retreat. The results of Regard et al. (2012) using a steady-state retreat model demonstrated that the position of the peak is sensitive to the tidal range and the platform gradient. Tidal range was held constant for all of our simulations; however, platform gradient declined during transient platform evolution simulations. Comparison of field measurements of ${ }^{10} \mathrm{Be}$ concentrations and model runs that assume steady-state retreat may therefore reveal when platform gradients are declining through time based on a mismatch in the position of the observed and modelled peak concentrations. In this case, the magnitude of the peaks suggests similar cliff retreat rates whether assuming steady-state or transient shore profile evolution.

In scenario (ii) cliff retreat rates tended toward a constant rate with the result that the distribution of ${ }^{10} \mathrm{Be}$ was approximately constant through time (Fig. 14). The concentrations of ${ }^{10} \mathrm{Be}$ were not consistent with a steady-state evolution scenario in which the platform gradient is fixed, which predicted roughly twice the amount of ${ }^{10} \mathrm{Be}$ for a particular position on the platform. The difference can be explained by the dissimilar platform morphology brought about by uneven distribution of platform downwear in the transient model simulations. Greater rates of downwear in the intertidal zone lower the platform more rapidly in the near-shore zone, which removes ${ }^{10} \mathrm{Be}$-laden rock and results in deeper water in the near-shore zone (and therefore reduced ${ }^{10} \mathrm{Be}$ production) than in the steady-state model runs that assume constant $\alpha$. These differences may be exacerbated when taking into account the spatial distribution of other processes such as weathering, the spatial distribution of which is currently poorly understood (Porter et al., 2010). In attempting to reconstruct cliff retreat rates the elevation profile of the platform should be accounted for such that the distribution of downwear across the platform is taken into account. Failure to do so would result in over-prediction of erosion rates since faster retreat rates would be required to match the lower concentrations observed on the platform. Accounting for the distribution of downwear would be aided by data on the distribution of downwear rates from micro-erosion-meter measurements (e.g. Robinson, 1977; Porter et al., 2010), and there is evidence that rates measured over the short term (1-2 years) are consistent with rates measured over 3 decades (Stephenson et al., 2010, 2012). Nevertheless, it is still not clear whether it is appropriate to extrapolate these rates over centennial to millennial timescales required to accumulate measurable concentrations of ${ }^{10} \mathrm{Be}$ nor is it yet clear whether this result is consistent across different shore platforms around the world. Future studies that measure the distribution of ${ }^{10} \mathrm{Be}$ concentrations (both across the shore platform and at depth) at sites with long records of observed downwearing rates would be an important next step in this line of enquiry.

\subsection{Beach cover}

Beach cover in the near-shore zone partially shields the underlying platform from ${ }^{10} \mathrm{Be}$ accumulation and results in a reduction in the magnitude of the hump. Yet we suggest that the significant reductions are only observed for relatively high beach widths $(\geqslant 50 \mathrm{~m})$ that are only likely to persist on slowly eroding coastlines since they may absorb wave energy and partially protect the cliff line. Theoretical considerations suggest a dynamic relationship between beach material and 
cliff retreat; beaches can act both to provide abrasive tools to enhance cliff erosion or to protect the cliff from wave energy (e.g. Limber and Murray, 2011). Similarly, cliffs are an important supply of material that makes up beaches; accelerated cliff retreat might allow beaches to build and shield the platform from cosmic rays. We did not model this dynamism but instead favoured the exploration of simple relationships between beach dynamics and the accumulation of ${ }^{10} \mathrm{Be}$ in the platform in order to try and understand first-order controls. We found that variation in beach cover through time was not important for ${ }^{10} \mathrm{Be}$ concentrations on a shore platform when compared to a scenario with a constant and representative average beach width. Our approach treated cliff retreat rate as constant and gradual, thus not capturing feedbacks between beach cover and cliff retreat nor exploring the influence that stochastic mass wasting processes might have on the variability of beach cover.

\subsection{Inheritance of ${ }^{10} \mathrm{Be}$}

Predicted concentrations of ${ }^{10} \mathrm{Be}$ in shore platforms are relatively low compared to typical applications in geomorphic studies. Cosmogenic ${ }^{10} \mathrm{Be}$ produced at the surface is dominated by spallation reactions, but muogenic production penetrates deeper into the Earth surface (Heisinger et al., 2002b, a; Braucher et al., 2013). Muons only account for a small fraction of the production once the platform is exposed, but platforms may already contain an appreciable concentration of ${ }^{10} \mathrm{Be}$ prior to exposure formed by deep-penetrating muons over much longer timescales. The amount of "inherited" ${ }^{10} \mathrm{Be}$ will decline with the depth below the top of the cliff (i.e. the cliff height) but is also influenced by the rate of surface lowering at the cliff top (Lal, 1991). It is important to collect near-shore samples to quantify how much inherited ${ }^{10} \mathrm{Be}$ is in the rock prior to platform exposure.

Platforms may also be geomorphically inherited landforms, having formed during a previous interglacial sea level high stand (e.g. the Eemian; 130-115 ka) and reoccupied by the sea during the Holocene (e.g. Trenhaile, 2001; Chao et al., 2003; Choi et al., 2012). If shore platforms are contemporary features, ${ }^{10} \mathrm{Be}$ concentrations will be low and their distribution controlled primarily by cliff retreat rate and other factors explored in this paper. If shore platforms are inherited features then ${ }^{10} \mathrm{Be}$ concentrations will be substantially higher, reflecting subaerial exposure during the last glacial period (Choi et al., 2012). The location of a sudden increase in ${ }^{10} \mathrm{Be}$ concentrations on the shore platform may reveal the location of the paleao-cliff line formed the previous time the shore platform was occupied, allowing a long-term average cliff retreat rate to be determined from the difference to the modern cliff position (Regard et al., 2012).

\subsection{Interpreting rates of cliff retreat from ${ }^{10} \mathrm{Be}$ concentrations}

In order to determine the rates of cliff retreat from ${ }^{10} \mathrm{Be}$ concentrations on shore platforms, the results of a coupled morphological and ${ }^{10} \mathrm{Be}$ production model are compared to measured concentrations in order to statistically determine the most likely combinations of parameters and retreat rates that yield a close fit between modelled and observed concentrations (Regard et al., 2012). In addition to high rates of cliff retreat, topographic shielding (Fig. 4) due to adjacent sea cliffs and the presence of beaches (Fig. 8) that may have previously been more extensive (Fig. 11) all act to reduce the amount of

${ }^{10} \mathrm{Be}$ in the shore platform, compared to a scenario with no cliffs and no beaches. Therefore, not accounting for the presence of beach material and topographic shielding is likely to lead to an overestimation of the rates of sea cliff retreat. Regard et al. (2012) did not account for beach cover and how it may have changed through time but observed beaches are relatively narrow and thin, and the cliffs at their field site were small enough to have negligible effect on their estimated cliff retreat rates, given uncertainties in their ${ }^{10} \mathrm{Be}$ concentration measurements.

Observations of beach widths and berm heights may be made from both modern and historical data (e.g. Dornbusch et al., 2008), but there is little information about how beaches may have changed over millennial timescales. However, exposed shore platforms are most likely to be associated with locations with little or declining beach cover, since if beaches were accumulating, the platform would not be exposed and cliff retreat rates might be expected to drop. The model predicts minimal differences in the distribution of ${ }^{10} \mathrm{Be}$ concentrations in the shore platform surface for simulations with constant vs. variable beach cover (Fig. 10). A representative average beach width guided by historical observations may suffice when interpreting cliff retreat rates from ${ }^{10} \mathrm{Be}$ concentrations.

\section{Conclusions}

We find that the accumulation of ${ }^{10} \mathrm{Be}$ in the shore platform is primarily sensitive to the rate of cliff retreat. Concentrations of ${ }^{10} \mathrm{Be}$ in the shore platform are also influenced by a number of other factors, including topographic shielding by sea cliffs, shielding due to beach and talus cover, water shielding due to tides and relative sea level change, the type of processes eroding the platform, and the style of platform evolution (steady state vs. transient). These factors generally tend to reduce the production of ${ }^{10} \mathrm{Be}$ in the shore platform, particularly in the near-shore zone, nearest to cliffs and where the platform is most likely to be covered by a beach. Nevertheless, comparison of measured ${ }^{10} \mathrm{Be}$ concentrations to model simulations that include these factors should allow determination of longterm average cliff retreats. If these factors are not adequately considered, then there will be a tendency to over-predict cliff 
retreat rates, and so cliff retreat rates derived from cosmogenic ${ }^{10} \mathrm{Be}$ might be considered as maximum estimates. The shape of the distribution of ${ }^{10} \mathrm{Be}$ across a shore platform can reveal whether cliff retreat rates are declining or accelerating through time. We conclude that measurement of ${ }^{10} \mathrm{Be}$ in shore platforms has great potential to allow us to quantify long-term rates of cliff retreat and platform erosion.

\section{Data availability}

The topographic and tide data used in this paper are available from the Channel Coast Observatory at www.channelcoast. org. All code used in this analysis is open source and can be downloaded from https://mdhurst1.github.io/RoBoCoP CRN_Documentation/. Model code can be downloaded from Hurst (2017), and the data and plotting scripts used to create the figures for this paper are available from Hurst et al. (2017).

Author contributions. Martin D. Hurst, Dylan H. Rood and Michael A. Ellis conceived the study; Martin D. Hurst wrote the software and performed the analyses; Martin D. Hurst wrote the paper with contributions from all authors.

Acknowledgements. We are grateful to Robert Anderson, Uwe Dornbusch, Zuzanna Swirad and Nick Rosser for discussion that shaped the development of this study and for reviews from Mark Dickson, Vincent Regard and Alan Trenhaile that allowed us to improve the paper. This paper is published with the permission of the Executive Director of the British Geological Survey and was funded by the Land, Soil, and Coast research programme (BGS05002).

Edited by: J. Willenbring

Reviewed by: M. Dickson and A. Trenhaile

\section{References}

Anderson, R. S., Densmore, A. L., and Ellis, M. A.: The generation and degradation of marine terraces, Basin Res., 11, 7-19, doi:10.1046/j.1365-2117.1999.00085.x, 1999.

Ashton, A. D., Walkden, M. J. A., and Dickson, M. E.: Equilibrium responses of cliffed coasts to changes in the rate of sea level rise, Mar. Geol., 284, 217-229, doi:10.1016/j.margeo.2011.01.007, 2011.

Balco, G., Stone, J. O., Lifton, N. A., and Dunai, T. J.: A complete and easily accessible means of calculating surface exposure ages or erosion rates from ${ }^{10} \mathrm{Be}$ and ${ }^{26} \mathrm{Al}$ measurements, Quat. Geochronol., 3, 174-195, doi:10.1016/j.quageo.2007.12.001, 2008.

Barkwith, A., Hurst, M. D., Thomas, C. W., Ellis, M. A., Limber, P. L., and Murray, A. B.: Coastal vulnerability of a pinned, softcliff coastline, II: assessing the influence of sea walls on future morphology, Earth Surf. Dynam., 2, 233-242, doi:10.5194/esurf2-233-2014, 2014.
Bradley, S. L., Milne, G. A., Shennan, I., and Edwards, R.: An improved glacial isostatic adjustment model for the British Isles, J. Quaternary Sci., 26, 541-552, doi:10.1002/jqs.1481, 2011.

Braucher, R., Merchel, S., Borgomano, J., and Bourlès, D. L.: Production of cosmogenic radionuclides at great depth: A multi element approach, Earth Planet. Sc. Lett., 309, 1-9, doi:10.1016/j.eps1.2011.06.036, 2011.

Braucher, R., Bourlès, D., Merchel, S., Vidal Romani, J., FernadezMosquera, D., Marti, K., Léanni, L., Chauvet, F., Arnold, M., Aumaître, G., and Keddadouche, K.: Determination of muon attenuation lengths in depth profiles from in situ produced cosmogenic nuclides, Nucl. Instrum. Meth. B, 294, 484-490, doi:10.1016/j.nimb.2012.05.023, 2013.

Bray, M. J. and Hooke, J. M.: Prediction of soft-cliff retreat with acceleration sea-level rise, J. Coastal Res., 13, 453-467, 1997.

Brooks, S. M. and Spencer, T.: Temporal and spatial variations in recession rates and sediment release from soft rock cliffs, Suffolk coast, UK, Geomorphology, 124, 26-41, doi:10.1016/j.geomorph.2010.08.005, 2010.

Bruun, P.: Coast Erosion and the Development of Beach Profiles, U.S. Army Beach Erosion Board Technical Memorandum 44, Vicksburg, Mississippi, USA, 44, 79 pp., 1954.

Chao, R. B., Casais, M. C., Cortizas, A. M., Alberti, A. P., and Trenhaile, A. S.: Evolution and inheritance of a rock coast: Western Galicia, Northwestern Spain, Earth Surf. Proc. Land., 28, 757775, doi:10.1002/esp.496, 2003.

Chmeleff, J., von Blanckenburg, F., Kossert, K., and Jakob, D.: Determination of the ${ }^{10} \mathrm{Be}$ half-life by multicollector ICP-MS and liquid scintillation counting, Nucl. Instrum. Meth. B, 268, 192 199, doi:10.1016/j.nimb.2009.09.012, 2010.

Choi, K. H., Seong, Y. B., Jung, P. M., and Lee, S. Y.: Using Cosmogenic ${ }^{10} \mathrm{Be}$ Dating to Unravel the Antiquity of a Rocky Shore Platform on the West Coast of Korea, J. Coastal Res., 282, 641657, doi:10.2112/JCOASTRES-D-11-00087.1, 2012.

Codilean, A. T.: Calculation of the cosmogenic nuclide production topographic shielding scaling factor for large areas using DEMs, Earth Surf. Proc. Land., 31, 785-794, doi:10.1002/esp.1336, 2006.

Costa, S., Delahaye, D., Freire-Diaz, S., Di Nocera, L., Davidson, R., and Plessis, E.: Quantification of the Normandy and Picardy chalk cliff retreat by photogrammetric analysis, Geol. Soc. Eng. Geol. SP., 20, 139-148, doi:10.1144/GSL.ENG.2004.020.01.11, 2004.

Dean, R. G. and Darlymple, R. A.: Coastal Processes with Engineering Applications, Cambridge University Press, Cambridge, UK, 2002.

Desilets, D., Zreda, M., and Prabu, T.: Extended scaling factors for in situ cosmogenic nuclides: New measurements at low latitude, Earth Planet. Sc. Lett., 246, 265-276, doi:10.1016/j.epsl.2006.03.051, 2006.

Dickson, M. E., Ogawa, H., Kench, P. S., and Hutchinson, A.: Sea-cliff retreat and shore platform widening: Steadystate equilibrium?, Earth Surf. Proc. Land., 38, 1046-1048, doi:10.1002/esp.3422, 2013.

Dornbusch, U. and Robinson, D. A.: Block removal and step backwearing as erosion processes on rock shore platforms: A preliminary case study of the chalk shore platforms of south-east England, Earth Surf. Proc. Land., 36, 661-671, doi:10.1002/esp.2086, 2011. 
Dornbusch, U., Robinson, D. A., Moses, C., Williams, R., and Costa, S.: Retreat of Chalk cliffs in the eastern English Channel during the last century, J. Maps, 2, 71-78, doi:10.4113/jom.2006.46, 2006.

Dornbusch, U., Robinson, D. A., Moses, C. A., and Williams, R. B. G.: Temporal and spatial variations of chalk cliff retreat in East Sussex, 1873 to 2001, Mar. Geol., 249, 271-282, doi:10.1016/j.margeo.2007.12.005, 2008

Dunai, T. J.: Cosmogenic nuclides, Cambridge University Press, Cambridge, UK, New York, USA, 1995.

Dunai, T. J.: Scaling factors for production rates of in situ production cosmogenic nuclides: a critical reevaluation, Earth Planet. Sc. Lett., 176, 157-169, 2000.

Dunne, J., Elmore, D., and Muzikar, P.: Scaling factors for the rates of production of cosmogenic nuclides for geometric shielding and attenuation at depth on sloped surfaces, Geomorphology, 27, 3-11, doi:10.1016/S0169-555X(98)00086-5, 1999.

Gosse, J. C. and Phillips, F. M.: Terrestrial in situ cosmogenic nuclides: theory and application, Quaternary Sci. Rev., 20, 14751560, doi:10.1016/S0277-3791(00)00171-2, 2001.

Granger, D. E., Lifton, N. A., and Willenbring, J. K.: A cosmic trip: 25 years of cosmogenic nuclides in geology, Bull. Geol. Soc. Am., 125, 1379-1402, doi:10.1130/B30774.1, 2013.

Heisinger, B., Lal, D., Jull, A., Kubik, P., Ivy-Ochs, S., Knie, K., and Nolte, E.: Production of selected cosmogenic radionuclides by muons: 2. Capture of negative muons, Earth Planet. Sc. Lett., 200, 357-369, 2002a.

Heisinger, B., Lal, D., Jull, J., Kubik, P., Ivy-Ochs, S., Neumaier, S., Knie, K., Lazarev, V., and Nolte, E.: Productioin of selected cosmogenic radionuclides by muons 1. Fast muons, Earth Planet. Sc. Lett., 200, 345-355, 2002 b.

Hurst, M. D.: RoBoCoP_CRN, Model Software, doi:10.5281/zenodo.259432, 2017.

Hurst, M. D., Barkwith, A., Ellis, M. A., Thomas, C. W., and Murray, A. B.: Exploring the sensitivities of crenulate bay shorelines to wave climates using a new vectorbased one-line model, J. Geophys. Res.-Earth, 120, 2586-2608, doi:10.1002/2015JF003704, 2015.

Hurst, M. D., Rood, D. H., Ellis, M. A., Anderson, R. S., and Dornbusch, U.: Recent acceleration in coastal cliff retreat rates on the south coast of Great Britain, P. Natl. Acad. Sci., 113, 1333613341, doi:10.1073/pnas.1613044113, 2016.

Hurst, M. D., Rood, D. H., and Ellis, M. A.: Controls on the distribution of cosmogenic 10Be across shore platforms, Data Collection, doi:10.5525/gla.researchdata.385, 2017.

Katz, O. and Mushkin, A.: Characteristics of sea-cliff erosion induced by a strong winter storm in the eastern Mediterranean, Quaternary Res., 80, 20-32, doi:10.1016/j.yqres.2013.04.004, 2013.

Kennedy, D. M., Stephenson, W. J., and Naylor, L. A.: Introduction to the rock coasts of the world, Geo. Soc. Mem., 40, 1-5, doi:10.1144/M40.1, 2014.

Komar, P. D. and Gaughan, M. K.: Airy Wave Theory and Breaker Height Prediction, Coast. Eng., 1972, 405-418, doi:10.1061/9780872620490.023, 1972.

Korschinek, G., Bergmaier, A., Faestermann, T., Gerstmann, U. C., Knie, K., Rugel, G., Wallner, A., Dillmann, I., Dollinger, G., von Gostomski, C. L., Kossert, K., Maiti, M., Poutivtsev, M., and Remmert, A.: A new value for the half-life of ${ }^{10} \mathrm{Be}$ by Heavy-Ion Elastic Recoil Detection and liquid scintillation counting, Nucl. Instrum. Meth. B, 268, 187-191, doi:10.1016/j.nimb.2009.09.020, 2010.

Lal, D.: Cosmic-ray labeling of erosion surfaces - in situ nuclide production-rates and erosion models, Earth Planet. Sc. Lett., 104, 424-439, doi:10.1016/0012-821X(91)90220-C, 1991.

Lifton, N. A., Bieber, J. W., Clem, J. M., Duldig, M. L., Evenson, P., Humble, J. E., and Pyle, R.: Addressing solar modulation and long-term uncertainties in scaling secondary cosmic rays for in situ cosmogenic nuclide applications, Earth Planet. Sc. Lett., 239, 140-161, doi:10.1016/j.epsl.2005.07.001, 2005.

Limber, P. W. and Murray, A. B.: Beach and sea-cliff dynamics as a driver of long-term rocky coastline evolution and stability, Geology, 39, 1147-1150, doi:10.1130/G32315.1, 2011.

Matsumoto, H., Dickson, M. E., and Kench, P. S.: An exploratory numerical model of rocky shore profile evolution, Geomorphology, 268, 98-109, doi:10.1016/j.geomorph.2016.05.017, 2016.

Mudd, S. M., Harel, M.-A., Hurst, M. D., Grieve, S. W. D., and Marrero, S. M.: The CAIRN method: automated, reproducible calculation of catchment-averaged denudation rates from cosmogenic nuclide concentrations, Earth Surf. Dynam., 4, 655-674, doi:10.5194/esurf-4-655-2016, 2016.

Naylor, L. A., Stephenson, W. J., Smith, H. C. M., Way, O., Mendelssohn, J., and Cowley, A.: Geomorphological control on boulder transport and coastal erosion before, during and after an extreme extra-tropical cyclone, Earth Surf. Proc. Land., 41, 685700, doi:10.1002/esp.3900, 2016.

Porter, N. J., Trenhaile, A. S., Prestanski, K., and Kanyaya, J. I.: Patterns of surface downwearing on shore platforms in eastern Canada, Earth Surf. Proc. Land., 35, 1793-1810, doi:10.1002/esp.2018, 2010.

Pugh, D. and Woodworth, P.: Sea-level science: understanding tides, surges, tsunamis and mean sea-level changes, Cambridge University Press, Cambridge, UK, 2014.

Recorbet, F., Rochette, P., Braucher, R., Bourlès, D., Benedetti, L., Hantz, D., and Finkel, R. C.: Evidence for active retreat of a coastal cliff between 3.5 and $12 \mathrm{ka}$ in Cassis (South East France), Geomorphology, 115, 1-10, doi:10.1016/j.geomorph.2009.04.023, 2010.

Regard, V., Dewez, T., Bourlès, D. L., Anderson, R. S., Duperret, A., Costa, S., Leanni, L., Lasseur, E., Pedoja, K., and Maillet, G. M.: Late Holocene seacliff retreat recorded by ${ }^{10} \mathrm{Be}$ profiles across a coastal platform: Theory and example from the English Channel, Quat. Geochronol., 11, 87-97, doi:10.1016/j.quageo.2012.02.027, 2012.

Robinson, L. A.: Erosive processes on the shore platform of northeast Yorkshire, England, Mar. Geol., 23, 339-361, doi:10.1016/0025-3227(77)90038-X, 1977.

Rogers, H. E., Swanson, T. W., and Stone, J. O.: Long-term shoreline retreat rates on Whidbey Island, Washington, USA, Quaternary Res., 78, 315-322, doi:10.1016/j.yqres.2012.06.001, 2012.

Stephenson, W. J., Kirk, R. M., Hemmingsen, S. A., and Hemmingsen, M. A.: Decadal scale micro erosion rates on shore platforms, Geomorphology, 114, 22-29, doi:10.1016/j.geomorph.2008.10.013, 2010.

Stephenson, W. J., Kirk, R. M., Kennedy, D. M., Finlayson, B. L., and Chen, Z.: Long term shore platform surface lowering rates: Revisiting Gill and Lang after 32 years, Mar. Geol., 299-302, 90-95, doi:10.1016/j.margeo.2012.01.005, 2012. 
Stone, J. O.: Air pressure and cosmogenic isotope production, J. Geophys. Res., 105, 23753, doi:10.1029/2000JB900181, 2000.

Sunamura, T.: Geomorphology of Rocky Coasts, J. Wiley, New York, USA, 1992.

Sunamura, T.: Review Rocky coast processes: with special reference to the recession of soft rock cliffs, P. Jpn. Acad. B-Phys., 91, 481-500, doi:10.2183/pjab.91.481, 2015.

Trenhaile, A. S.: Modeling the development of wave-cut shore platforms, Mar. Geol., 166, 163-178, doi:10.1016/S00253227(00)00013-X, 2000.

Trenhaile, A. S.: Modeling the effect of late Quaternary interglacial sea levels on wave-cut shore platforms, Mar. Geol., 172, 205223, doi:10.1016/S0025-3227(00)00136-5, 2001.

Trenhaile, A. S.: The effect of Holocene changes in relative sea level on the morphology of rocky coasts, Geomorphology, 114, 30-41, doi:10.1016/j.geomorph.2009.02.003, 2010.
Trenhaile, A. S.: Climate change and its impact on rock coasts, Geo. Soc. Mem., 40, 7-17, doi:10.1144/M40.2, 2014.

Walkden, M. J. A. and Hall, J. W.: A predictive Mesoscale model of the erosion and profile development of soft rock shores, Coast. Eng., 52, 535-563, doi:10.1016/j.coastaleng.2005.02.005, 2005.

West, A. J., Hetzel, R., Li, G., Jin, Z., Zhang, F., Hilton, R. G., and Densmore, A. L.: Dilution of ${ }^{10} \mathrm{Be}$ in detrital quartz by earthquake-induced landslides: Implications for determining denudation rates and potential to provide insights into landslide sediment dynamics, Earth Planet. Sc. Lett., 396, 143-153, doi:10.1016/j.eps1.2014.03.058, 2014. 